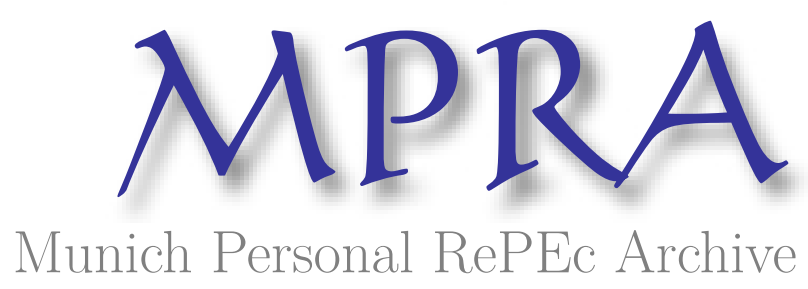

\title{
How Does Mortgage Debt Affect Household Consumption? Micro Evidence from China
}

Fan, Ying and Yavas, Abdullah

22 May 2017

Online at https://mpra.ub.uni-muenchen.de/79306/

MPRA Paper No. 79306, posted 25 May 2017 07:33 UTC 


\title{
How Does Mortgage Debt Affect Household Consumption? Micro Evidence from China
}

\author{
Ying Fan \\ Hang Lung Center for Real Estate \\ Institute of Real Estate \\ Tsinghua University \\ Beijing, 100084, P. R. China. \\ Email: fanying13@mails.tsinghua.edu.cn \\ and \\ Abdullah Yavas \\ Department of Real Estate and Urban Land Economics \\ School of Business \\ University of Wisconsin-Madison \\ Madison, WI 53706 \\ Email: yavas@wisc.edu
}




\title{
How Does Mortgage Debt Affect Household Consumption? Micro Evidence from China
}

\begin{abstract}
The high growth rate of mortgage debt in various emerging and developed economies has captured headlines following the financial crisis. In this paper, we investigate how mortgage debt impacts household consumption behavior and various components of household consumption. Utilizing a comprehensive household survey data from China, we show that households with a mortgage consume a higher portion of their income than households without a mortgage. This is in line with the argument that having a mortgage reduces the uncertainty that the household faces regarding how much to save each month in order to be able to own a house, and this reduced uncertainty leads to lower monthly savings for the purpose of buying a house. We also find that among households with a mortgage, those who spend a larger share of their income on mortgage payments spend less of their income on consumption, reflecting the crowding out effect of mortgage payments on household consumption. Furthermore, we show that a government policy of decreasing the maximum loan-to-value ratio has a significant impact on the consumption behavior of households. The current paper offers the first evidence of the impact of growing mortgage debt on the consumption behavior of households. Our results will have implications for government policies that encourage mortgage borrowing.
\end{abstract}

JEL Classification: E21, D14, G21

Keywords: Consumption, Mortgage Debt 


\section{Introduction}

The size and growth rate of mortgage debt and its impact on the consumption and saving behaviors of households are important questions for policy makers for a number of reasons. The primary reason is that housing constitutes a large share of the economy and is a significant component of household expenditure and household total wealth. Mortgage debt will influence residential investment, household wealth and household consumption. Furthermore, a low saving rate constrains the amount of investment that the economy can undertake, as there is a very close association between national saving and investment rates (Feldstein and Horioka, 1980). Thus, it is not surprising that economists and policy makers are concerned with the welfare implications of government policies that subsidize mortgage debt and provide financial incentives for home ownership. Mortgage debt is also important for monetary policy since the size and growth rate of mortgage debt has implications for the effectiveness of monetary policy (Calza et al., 2013).

In this paper, we focus on another reason policy makers should pay attention to the growth of mortgage debt. We study how mortgage debt effects household consumption and saving behavior. Having a mortgage loan has important implications for household consumption and saving decisions as it requires an initial deposit (i.e. down payment) to purchase a house and establishes monthly mortgage payments, and in return provides monthly accumulation of home equity. On the one hand, mortgage payments serve as a disciplining device for the borrower to save for these payments. It also induces young households to save for the initial down payment needed to obtain a mortgage loan. On the other hand, a mortgage loan reduces the uncertainty over the biggest purchase that a typical household makes in their lifetime. In the absence of a mortgage loan, one needs to save for an uncertain purchase price at an uncertain purchase date that will likely take place years later in the future. With a mortgage loan, the purchase price and monthly payments are determined upfront. Thus, having a mortgage loan significantly reduces the uncertainty that an agent faces 
regarding how much to save each month in order to be able to buy a house. This reduced uncertainty could lead to a significant reduction in household savings (Aiyagari, 1994).

We utilize data from a comprehensive household survey from China to study the impact of mortgage payments on household consumption. This is a unique data set in that it includes information on expenditures on various consumption items (food, clothing, education, medical, transportation, utilities and durables), mortgage and non-mortgage loan payments, assets, income, and various demographic characteristics of each household.

We find that households with a mortgage loan consume a higher portion of their income than households without a mortgage loan. This is in line with the argument that having a mortgage reduces the uncertainty that the household faces regarding how much to save each month in order to be able to own a house, and this reduced uncertainty about future cash flows leads to lower monthly savings for the purpose of buying a house. However, we also find that among households who hold a mortgage, those who spend a larger share of their income on mortgage payments spend less of their income on consumption, reflecting the crowding out effect of mortgage payments on household consumption. Furthermore, we show that a government policy of decreasing the maximum loan-to-value ratio has a significant impact on the consumption behavior of households.

The current paper offers the first micro evidence of the impact of mortgage debt on consumption behavior of households. Earlier studies of consumption and saving behavior have failed the incorporate the role of mortgage debt in their analyses (e.g. Campbell and Cocco, 2007; Ludwig and Slok, 2004; Juster, et al, 2003; Loayza et al, 2000; Japelli and Pagano, 1994; Engelhardt, 1996, and Skinner, 1988). Exceptions are two recent studies that investigated the role of mortgage debt on saving rates in the US and Turkey (Tunc and Yavas, 2016, 2017) and found significant and sizable negative impact of mortgage debt growth on 
saving rates in those two countries, but these two studies had to rely on macro level data. The current study will help us improve our understanding of the consumption and saving behaviors of households, and will have implications for monetary policy and government policies that encourage mortgage borrowing.

The rest of the paper is organized as follows. In the next section, we provide a discussion of the background and present the motivation for this paper. In the third section, we present the empirical analysis of the saving rate and the data for the analysis. The results are presented in the fourth section. The fifth section discusses the results and the last section concludes.

\section{Emerging Mortgage Market and Household Consumption in China}

The acceleration of economic development over the last two decades has greatly affected the housing prices and wealth of urban Chinese households. From 2004 to 2014, housing prices have grown persistently at an average annual rate of $10.7 \%$, about 3.92 times higher than that from 1998 to 2003, according to the China Statistics Yearbook. This price growth significantly stimulates the accumulation of housing wealth of households. According to the data from the National Bureau of Statistics of China, urban households spent a total of 43.4 trillion RMB on housing purchase during the period from 2000 and 2014, of which over 7 trillion RMB occurred in 2014. The share of housing assets in total net wealth rose from $44 \%$ in 2002 to $73.9 \%$ in 2012.

Paralleled with the rapid growth of housing assets in China is the emerging mortgage market. Since 1998, China has experienced a transformation from a traditional welfare housing system towards a market-oriented housing system. The mortgage market was introduced into the Chinese financial system 
during this transformation to promote home buying.

The high growth rate of mortgage debt in China has recently captured headlines around the world. Mortgage debt has accounted for more than $70 \%$ of all new lending in China in recent months, up from an average of 33\% in 2015 (WSJ, Oct 17, 2016). Bloomberg pointed to mortgage debt growth in China with a provocative headline: "Is China Building a Mortgage Bomb?"1 Figure 1 illustrates that the growth of mortgage debt in China is not a recent phenomenon. The ratio of mortgage debt to GDP has been steadily increasing since the turn of the century. Furthermore, with total outstanding mortgage debt still below $20 \%$ of GDP, the Chinese mortgage market has a lot of additional room to grow. Thus, the issue of high growth rate of mortgage debt will be a topic of discussion in China in the coming years.

Similarly, the portion of households that hold a mortgage loan has also increased rapidly. According to the Urban Household Survey conducted by National Bureau of Statistics, 26.6\% of homebuyers in urban China obtained a mortgage loan in 2009, which is double the ratio in 2002 (12.2\%).

Mortgages in China are adjusted rate mortgages (ARM), and there are no alternative mortgage instruments available to borrowers. Mortgages are all purchase mortgages and second mortgages are not readily available. $^{2}$

In addition to commercial banks, financing is available to homebuyers in China from the Housing Provident Fund (HPF), one of the principal financial institutions supporting homeownership in China. The HPF encourages workers to save a portion of their income to buy residential properties. Similar to Singapore's scheme, when an employee registers with the HPF, the employer opens a bank account under the employee's name. The employee contributes $5 \%$ of his monthly salary and the employer deposits the same amount. Employees cannot withdraw this money unless they retire, pass away, or leave the job, but

\footnotetext{
${ }^{1}$ http://origin-www.bloombergview.com/articles/2014-11-21/is-china-building-a-mortgage-bomb

2 All mortgage loans in China have floating rates; decreases in interest rates do not motivate mortgage refinancing 
they can use the funds to purchase residential properties with a below market loan rate from state-owned banks.

It should also be noted that informal borrowing amongst friends and relatives is also prevalent in China. According to statistics from the China Household Finance Survey (CHFS) in 2013, more than 32\% of total homebuyers in China informally borrowed from friend and relatives. The average amount borrowed from friends and family is $70,300 \mathrm{RMB}$ per family, and the average reported interest rate of informal borrowing is $0.43 \%$, which is significantly lower than a deflated deposit interest rate and medium/long-term loan interest rates published by Central Bank of China (6.55\% in 2013).

In contrast with the surging wealth accumulation, household consumption in China as measured by the ratio of household consumption to income reached its lowest level in 2014, with a share of only $45.1 \%$ (see Figure 2). This ratio is much smaller than the ratio in OECD countries where the share of consumption in GDP is consistently larger than $70 \%$.

The consumption-saving pattern in China is significantly influenced by two factors: strong precautionary motives and self-discipline. The precautionary motives were stimulated by the reforms that took place in labor markets, education and the health system, which increased the volatility of income and expenditures (Chamon and Prasad, 2008). While government expenditures on education and health lagged behind the GDP growth, household expenditures on these two items increased considerably over the years. Chinese consumption is also influenced by Confucian-centered core values such as thriftiness, social consciousness, and moderation (Wong and Ahuvia, 1998; Kindel, 1985). 


\section{Data and Empirical Design}

\subsection{Data}

We use data from the Urban Household Survey (UHS) conducted by the Chinese Statistics Bureau.

This survey was conducted in the years 2002 to 2009 and covers 118 cities located in nine provinces and municipalities. ${ }^{3}$ The data is unique and comprehensive since the survey contains a rich set of information on households' demographics; social economic conditions such as age, education level, occupation of household members; and households' income, assets and liabilities. Details on household expenditure on various consumption categories (food, clothing, residence (user cost), non-housing durable goods, medical services, transportation, education and miscellaneous services) and mortgage and non-mortgage debt payments are also included. The UHS uses the stratified random sampling method to select households for the survey. One third of households in the sample are replaced each year. After excluding all observations with null or abnormal values in key variables (such as households with negative income, housing areas exceeding 500 square meters, and housing values exceeding 100 million RMB), the sample includes 109,920 observations, of which 96,939 are home owners and the rest are renters. In $2002,12.2 \%$ of households that bought a house in the sample took out a mortgage loan. This ratio increased to $26.9 \%$ in 2009, yielding an annual growth rate of $10.2 \%$.

We also include the social and economic characteristics of the household, such as income ${ }^{4}$, education and employment status. In addition, we control for Hukou status ${ }^{5}$ as it determines access by the household to local public services such as education and medical insurance. We also include fanggaifang to control

\footnotetext{
3 These include Beijing, Chengdu, Dalian, Guangzhou, Hangzhou, Hefei, Lanzhou, Ningbo, Shenzhen, Shenyang, Wuhan and Xian.

${ }^{4}$ Income here denotes "household disposable income", which includes salary, subsidies, capital gains from financial assets and other income sources such as inter-generation transfers.

${ }^{5}$ Hukou refers to a household-registration record that officially identifies an individual as a resident of a given area. It is one of China's most important institutions, as it defines individuals' socio-economic status and access to welfare benefits.
} 
for privatized housing obtained at deep discounts, as it can lead to more rapid accumulation of housing wealth. ${ }^{6}$ As a proxy for the health conditions of household members, we use the household medical and healthcare expenditure relative to the regional average.

To capture the potential impact of capital gains on consumption, we use the housing price index estimated by the NBSC for each year and for each city, deflated by CPI. We also merged the household information with macroeconomic information from the provincial level, which includes growth rate of per capita real income and public saving rate. The data source of these variables is the Chinese Statistics Bureau. Descriptive statistics of the variables used in the study are presented in Table 1.

\subsection{Empirical Design}

In order to have a comprehensive understanding of the role of mortgage payment on household consumption, we first test the impact of having a mortgage loan on household consumption. Then, we focus on the subsample of households who have a mortgage and investigate how the mortgage payment rate, amount of mortgage payment as a percentage of their disposable income, impact their consumption rate. We also establish an interactive term of mortgage payment rate with whether the mortgage was newly acquired in the survey year in order to examine the role of having to make a down payment in that year. Considering different components of household consumption, we also study the impact of mortgage payments on eight categories of consumption: food, clothing, residence (user cost), non-housing durable goods, medical services, transportation, education and others.

\section{$\underline{\text { Role of Having a Mortgage Loan on Household Consumption }}$}

\footnotetext{
${ }^{6}$ After the 1998 housing reform, public housing was allocated to tenants at the time at below market prices.
} 
We recognize that having a mortgage is an endogenous choice variable. For this reason, we first estimate the probability of having a mortgage payment using a probit model, and then regress this estimated probability on household consumption rates. The empirical models are as follows.

$$
\begin{gathered}
\operatorname{Prob}\left(\text { Dmortgage }_{i}=1 \mid W_{i}\right)=\Phi\left(W_{i}^{T} \gamma\right) \\
\text { Dmortgage }_{\iota}=\Phi\left(W_{i}^{T} \gamma\right) \\
\text { consumption }_{i}=\alpha_{11}+\beta_{11} \text { Dmortgage }_{\imath}+\beta_{12} \Omega_{i}+\varepsilon_{1 i}
\end{gathered}
$$

where dummy variable Dmortgage $_{i}$ denotes whether the household has a mortgage payment in survey year. $W_{i}$ is a vector of explanatory variables impacting the household's mortgage acquisition decision that includes household financial and demographic information (household annual disposable income, household non-mortgage loan payment to disposable income ratio, household age structure, whether household owns a house, total asset value of assets owned by the household, household head's marriage status, age, age square, HUKOU status and health condition), macroeconomic conditions at the provincial level (average selling price of housing units, housing price appreciation rate over the previous year, annual growth rate of average income in the province). $\gamma$ is a vector of unknown parameters estimated by maximum likelihood. $\Phi$ is the cumulative distribution function of the standard normal distribution. Dmortgage $e_{\imath}$ is the estimated probability of having a mortgage. consumption con $_{i}$ is the ratio of consumption to disposable income for household $i$, where we run the consumption regression for total consumption and for each of the subcategories of consumption: totalratio, foodratio, clothratio, residentratio, durableratio, medicalratio, transratio, educateratio, and otherratio. D_mortgage $e_{i}$ is the estimated probability of having a mortgage payment using the probit regression. $\Omega_{i}$ is a vector of control 
variables that includes the same variables as in $W_{i}$ except for the housing price appreciation. Year and regional fixed-effects are also controlled in all regressions.

\section{$\underline{\text { Role of Mortgage Payment on Household Consumption }}$}

In this part, we focus on households that hold a mortgage payment and test how their mortgage payment rate affects their consumption rate. In order to control for potential sample selection bias, we first calculate and control for the inverse Mills ratio:

$$
\begin{gathered}
\operatorname{Prob}\left(\text { Dmortgage }_{i}=1 \mid W_{i}\right)=\Phi\left(W_{i}^{T} \gamma\right) \\
\text { lambda_mortgage } e_{i}=\frac{\phi\left(W_{i}^{T} \gamma\right)}{\Phi\left(W_{i}^{T} \gamma\right)}
\end{gathered}
$$

where $W_{i}$ is a vector of explanatory variables impacting a household's mortgage acquisition decision and $\gamma$ is a vector of unknown parameters, as defined before. $\phi$ is the density of the distribution function of the standard normal distribution, while $\Phi$ is the cumulative distribution function of the standard normal distribution. lambda_mortgage $i_{i}$ is the inverse Mills ratio of whether the household has a mortgage payment or not in the survey year.

We then control for the inverse Mills ratio in the consumption regressions,

$$
\text { consumption }_{i}=\alpha_{21}+\beta_{21} \text { mpayratio }_{i}+\beta_{22} \Omega_{i}+\text { lambda_mortgage } e_{i}+\varepsilon_{2 i}
$$

Next, we test the impact of acquiring a new mortgage on household consumption. Since acquiring a new mortgage involves making a down payment, and since a new mortgage may also stimulate some additional housing related expenditures (furniture, appliances, etc.), we expect an additional impact on household consumption in the year of mortgage origination. ${ }^{7}$ The down payment could come from savings or informal channels (loan from relatives and friends). If the down payment comes primarily from

\footnotetext{
${ }^{7}$ Down payment can play a particularly significant role in China, where the maximum loan-to-value ratio is set by the monetary authority and is often as low as $80 \%$.
} 
household savings, we would see a negative pressure on consumption until the loan is originated, and a possible relaxation of the pressure once the down payment is incurred.

In order to test whether there is a significant difference between a new mortgage and an old mortgage, we establish an interaction term of mortgage payment ratio and new mortgage dummy and include it in the consumption regression,

consumption $_{i}$

$$
\begin{aligned}
& =\alpha_{31}+\beta_{31} \text { mpayratio }_{i}+\beta_{32} \text { mpayratio }_{i} \times \text { newmortgage } \\
& +\beta_{33} \text { newmortgage }_{i}+\beta_{34} \Omega_{i}+\text { lambda_mortgage }_{i}+\varepsilon_{3 i}
\end{aligned}
$$

where. mpayratio $_{i} \times$ newmortgage $_{i}$ denotes the interaction term of mortgage payment ratio and whether the mortgage is acquired in the survey year.

\section{$\underline{\text { Policy Impact }}$}

A macroprudential policy measure commonly used in China that affects mortgages applications is the minimum down payment ratio, or the maximum loan-to-value. It is straightforward that a change in the policy of minimum down payment ratio should have no effect on the consumption behavior of those households that have already obtained a mortgage. However, a change in the policy is likely to impact consumption of those households that are planning to obtain a mortgage and saving for the down payment.

Table 2 compiles policy measures taken by the Chinese authorities that target housing and mortgage markets. Focusing on minimum down payment measures, we can divide our sample into two subsamples: years of 'mortgage tightening' where the minimun down payment ratio was increased, and years of 'mortgage loosening" where the minimun down payment ratio was decreased. The tightening years include 2005, 2006 and 2007, while loosening years include 2002, 2003, 2004, 2008 and 2009. We then 
build the dummy variable tighten $_{i}$, which takes the value of 1 when household $i$ obtains a new mortgage in a tightening year. We also create an interaction term of tighten variable with mortgage payment ratio and new mortgage dummmy to further investigate the impact of a change in down payment policy on household consumption. In doing so, we also control for the 5-year benchmark interest rate, as a change in minimum downpayment policy is often accompanied with a change in the benchmark interest rate policy.

We first utilize the entire sample of households and introduce an interaction term of the estimated probability of having a mortgage payment and the tighten dummy variable. The empirical model is as follows.

consumption $_{i}$

$$
\begin{aligned}
& =\alpha_{41}+\beta_{41} D_{-} \text {mortgage }_{i}+\beta_{42} \text { Dmortgage }_{\iota} \times \text { tighten }_{i}+\beta_{43} \text { tighten }_{i} \\
& +\beta_{44} \text { interest }_{i}+\beta_{45} \Omega_{i}+\varepsilon_{4 i}
\end{aligned}
$$

where Dmortgage $_{\iota} \times$ tighten $_{i}$ denotes the interaction term of estimated probability of having a mortgage payment and whether it is a tightening year, and interest ${ }_{i}$ denotes the 5 -year benchmark interest rate set by the People's Bank of China.

We then focus on those households that have a mortgage and introduce an interaction term of the mortgage payment ratio, whether the mortgage is acquired in the survey year, and whether it is a year of tightening. The empirical model is as follows.

consumption $_{i}$

$$
\begin{aligned}
& =\alpha_{51}+\beta_{51} \text { mpayratio }_{i}+\beta_{52} \text { mpayratio }_{i} \times \text { newmortgage }_{i} \times \text { tighten }_{i} \\
& +\beta_{53} \text { mpayratio }_{i} \times \text { newmortgage }_{i}+\beta_{54} \text { mpayratio }_{i} \times \text { tighten }_{i}+\beta_{55} \text { newmortgage }_{i} \\
& +\beta_{56} \text { mpayratio }_{i} \times \text { tighten }_{i}+\beta_{57} \Omega_{i}+\text { lambda_mortgage }_{i}+\varepsilon_{5 i}
\end{aligned}
$$


where mpayratio $_{i} \times$ newmortgage $_{i} \times$ tighten $_{i}$ denotes the interaction term of mortgage payment ratio, whether the mortgage is acquired in the survey year, and whether it is a tightening year. Since mortgages in China are all adjusted rate mortgages (ARM) and there are no alternative mortgage instruments available to borrowers, any change in the mortgage interest rate is already reflected in the mortgage payment ratio. Thus, there is no need to control for the mortgage interest rate for this sample where we focus on households that have a mortgage and where we control for mortgage payment ratio.

\section{Empirical Results}

\subsection{Role of Having a Mortgage on Household Consumption}

The results of the impact of having a mortgage on household consumption are shown in Table 3 . The first column reports the probit estimation of whether a household holds a mortgage payment. We find that household demographic and economic characteristics including age, family structure and income/asset holdings have a significant impact on the likelihood of obtaining a mortgage loan. The second column shows the impact of having a mortgage loan on household total consumption propensity. The coefficient of Dmortgage is positively significant, and it indicates that when the probability of having a mortgage increases by 1 percentage point, the household's total consumption ratio will increase by about 0.44 percentage points. The stimulating effect of a mortgage loan on household consumption can be primarily attributed to the uncertainty factor mentioned earlier in the paper; households who have already managed to obtain a loan and purchased a house do not need to save for an uncertain purchase price, with an uncertain down payment requirement, at an uncertain purchase date in the future. Since the purchase price and monthly payments are determined upfront, households with a mortgage will have less precautionary 
motivation to save compared to households that still need to be concerned about uncertainty regarding how much to save each month in order to be able to buy a house in the future.

When we look at different subcategories of household consumption, we find that having a mortgage will not only affect the amount of consumption, but also shape the composition of consumption.

According to Columns (3) to (10), having a mortgage will have different effects on household non-durable/durable consumption, housing related expenses and human capital expenditure. More specifically, households with a mortgage will increase expenditures on food and transportation but reduce their consumption of clothing. As expected, having a mortgage will also promote consumption in residential related expenditures (including decoration costs, water and electricity fees, property fees, etc.) as these expenditures are highly correlated with housing ownership. We do not find a significant impact of having a mortgage on education and medical expenditures, indicating relative rigidity in these human capital related expenses.

\subsection{Role of Mortgage Payment on Household Consumption}

The results for the impact of mortgage payment ratio on household consumption rate are shown in Table 4. Column (1) uses the entire sample and shows the first stage of Heckman procedure using probit model, which is the same as the first column of Table 3. In the remaining columns of Table 4, the sample includes households that hold a mortgage loan. The positive inverse Mills ratio in Column (2) indicates a potential upward bias under OLS estimation due to sample selection bias. Column (3) shows that among the households with a mortgage, controlling for sample selection bias, a higher mortgage payment ratio leads to a lower total consumption ratio. Quantitatively, a 1 percentage point increase in mortgage payment to income ratio leads to a 0.237 percentage point decrease in the consumption ratio. This is 
consistent with the substitution argument that higher mortgage payment ratio crowds out the consumption ratio. This result, combined with the earlier result of Table 3, shows that once the consumption stimulating impact of reducing house purchase price uncertainty is accounted for, as a household spends more of its income on mortgage payments, it will spend less of its income on consumption. In addition, we find that the mortgage payment ratio also impacts the composition of consumption. Generally, with a higher mortgage payment ratio, households spend less of their income on food, clothing, transportation, education and medical care. When it comes to housing related expenditures, we find that mortgage payment ratio does not have a significant impact on residential and durable goods expenditures.

Table 5 illustrates the role of down payment on household consumption by differentiating between old and newly obtained mortgages. We find that the interaction term of mortgage payment ratio and whether it is a newly obtained mortgage is not significant for the total consumption ratio and for all except one of the subcategories of consumption. This is likely due to the fact that a large percentage of households in China turn to their relatives and friends to borrow for their down payments. According to the China Household Finance Survey (CHFS), over 32\% of home owners in 2013 obtained informal borrowing from their relatives and friends for their home purchases. ${ }^{8}$

\subsection{Policy Impact}

In this section we investigate the impact of a change in down payment policy. The results are exhibited in Table 6 and Table 7.

\footnotetext{
8 Also, according to the CHFS database, the average reported interest rate of informal borrowing is $0.43 \%$, which is significantly lower than the deflated deposit interest and medium/long-term loan interest rates published by the Central Bank of China (6.55\% in 2013). 
In Table 6, we include the interaction term of estimated probability of having a mortgage with the dummy variable of tightening minimum down payment policy. As expected, the coefficient of the interaction term is not significant for total consumption ratio, since tightening of minimum down payment policy will not change the monthly mortgage payment ratio of households who already have a mortgage, once controlled for interest rates.

However, when we focus on new mortgages, as expected, we obtain different results. As shown in Table 7, the coefficient of triple interaction term mpayratio $\times n e w m o r t g a g e \times t i g h t e n$ is significant and negative. This denotes that households who obtain a mortgage in a tightening period and have a higher mortgage payment rate will have a lower consumption rate, and this decrease in consumption rate comes mainly from the decline in their residential expenditures. Thus, the down payment of new mortgages becomes effective when the mortgage is obtained during a tightening period. In such periods, the amount borrowed from friends and family cease to be sufficient to eliminate the impact of having a new mortgage. When the central bank raises the ratio of required down payment to total mortgage loan, households need to pay a significantly higher amount of down payment with their own funds, and this reduces their consumption. This finding is also consistent with earlier studies on down payment and private saving rate (Japelli and Pagano, 1994; Engelhardt, 1996; Tunc and Yavas, 2016), which highlight that requiring a larger down payments leads to a significant increase in household savings. We also find that, after controlling for the policy interaction, the coefficient of mpayratio is still negatively significant, reflecting the crowding out effect of mortgage payment on household consumption. We also find that households with a higher mortgage payment ratio will decrease their non-housing expenditures, including food, clothes, transportation, education and medical care, as in our earlier regressions. This further confirms our former findings. 


\subsection{Robustness Check}

As mentioned in the theoretical part, there could be an endogeneity problem between mortgage access/demand and household consumption decisions. On the one hand, households need their own equity to pay for the down payment, and thus the consumption pattern could impact their savings for the down payment, which in turn could affect their ability and decision to obtain a mortgage. On the other hand, there could be structural differences in the mortgage-consumption relationship across heterogeneous households, which would give rise to omitted variable problems. In this section, we will use two methods to address this issue.

\section{Instrumental variable}

We first involve instrumental variables and use the 2SLS to address the problem directly. As is well known, making good borrowing decisions would require borrowers to have an understanding of the characteristics of mortgage products, their features and the potential risks inherent in them. This financial knowledge could come from general human capital (e.g., education and age), or from a specific form of human capital, such as financial literacy (Lusardi and Mitchell, 2007). Financial literacy focuses on a person's skill and confidence in applying personal finance knowledge (Huston, 2010), which is directly correlated to household investment and financing decisions. Intuitively, financial literacy will impact household consumption behavior through household mortgage decisions (Cox, et al., 2015), which satisfies the condition for an instrumental variable. Unfortunately, the UHS database doesn't contain any information on direct measures of household financial literacy. We thus use the job background of the household head (whether the household head has worked in the financial sector and real estate sector) as a 
proxy of financial literacy. ${ }^{9}$ This instrument has two advantages. First, this kind of information is accessible. Second, a decision to enter the mortgage market tends to be endogenous to financial literacy, and literacy itself can be improved by experiencing and participating in the mortgage market. It has been shown that previous financial experience is an important aspect of financial literacy (Hogarth and Hilgert, 2002) and that specialized training or education enhances a person's financial literacy and promotes mortgage access (Hogarth and Hilgert, 2002; Lusardi and Tufano, 2009). The Durbin-Wu-Hausman test gives values of 5.98114 ( $\mathrm{p}$ value equals to 0.0145 ) for probability of having a mortgage (Dmortgage), which indicates there exists endogeneity in the variable Dmortgage. Meanwhile, the F statistics in the first state estimation is 288.60 (p value equals to 0), which is larger than "2SLS Size of nominal 5\% Wald test" (16.38), which indicates there is no weak instrument problem. The regression results are shown in Table 8. After correcting for the endogeneity bias, we find that having a mortgage will have a positive impact on a housheold's consumption ratio, which is consistent with our former finding.

\section{Propensity Score Matching (PSM)}

When we estimate the causal effect of mortgage payment ratio on household consumption ratio, we might face omitted variable bias (selection bias) arising from unobserved and uncontrolled differences between the two groups we compare, one with a mortgage and the other one with no mortgage.

As a statistical matching technique, PSM is commonly used to eliminate causal inference and systematic bias. Using logit regression, PSM employs the predicted probability of the observed group to

\footnotetext{
9 It should be noted that, given the relative low returns and immature development of capital markets in China, housing has become the most attractive asset for Chinese households. The annualized rate of return in China's domestic A-share market was only $1.8 \%$ during the last two decades, whereas the annual growth in housing price was $10.71 \%$. The average yield of the first housing units owned by Chinese households is $340.3 \%$, and the second and third units yield as much as $143.3 \%$ and $96.7 \%$. The mean value of urban residents' financial assets is RMB112,000, and their mean housing assets are 8.3 times greater, according to the 2011 Chinese Household Financial Investigation Report.
} 
create a corresponding counterfactual group, to control for the structural differences between the two groups to make the treatment group and not-treatment group more comparable. The kernel density of Propensity Score between the two groups before and after PSM is exhibited in Figure 3, which indicates that PSM has eliminated the significant distribution differences that existed before PSM.

Adopting PSM, we first estimate the probability of having a mortgage payment, and treat the households who have the closest probability to having a mortgage payment but actually did not have a mortgage as the corresponding counterfactual group. Then, we establish the interaction term of estimated probability of having mortgage and mortgage payment ratio to test the impact of mortgage payment on household consumption. The result is demonstrated in Table 9. We find that, after correcting the random selection bias, having a bigger mortgage payment ratio decreases a household's consumption ratio, which is consistent with our earlier conclusions.

One possible concern is that some of the households without a mortgage could be homeowners already. As a result, they do not suffer from the uncertainty of future payments that non-mortgage holders are expected to face. This is a particularly relevant issue in China where the homeownership rate is very high and where a significant portion of home purchases are made with cash. ${ }^{10}$ Thus, in our sample, the comparison between households with a mortgage payment and households without a mortgage payment may not fully capture the uncertainty reduction benefit of having a mortgage, hence undermining the representativeness of our estimations.

To address this issue, we next compare the consumption behaviors of mortgagors and renters, rather than comparing that of mortgagors and non-mortgagors. This comparison makes the impact of mortgage debt on household consumption more precise as we no longer need to worry about homeowners who have

\footnotetext{
10 According to the Chinese Family Financial Report in 2012, the housing ownership rate has already reached $85.39 \%$ in urban China, which significantly exceeds the housing ownership rate in the United States (65\%) and Japan (60\%). Meanwhile, according to the China Household Finance Survey (CHFS 2013), 30\% of households purchase their house in cash.
} 
already paid off mortgage debt or have never obtained a mortgage in purchasing their house. In comparing mortgagors and renters, we again use PSM, whereby we estimate the probability of having a mortgage payment and treat the renters who have the closest probability to having a mortgage payment as the counterfactual group.

As displayed in Table 10, we find a robust significant positive coefficient of the interaction term, which implies that, compared to renters, mortgagors with a bigger mortgage payment ratio will have a lower consumption ratio. What is also important to note is that having a mortgage loan has a positive and significant impact on consumption ratio. Note that the coefficient of having a mortgage loan in Table 9 was smaller and statistically insignificant. Thus, as expected, focusing on renters and mortgage holders increases the magnitude and significance of the impact of having a mortgage. This comparison also supports the argument that having a mortgage increases consumption rate by reducing the uncertainty that the household faces regarding future home purchase price and savings needed for the down payment and mortgage payments.

\section{$\underline{\text { Risk Aversion }}$}

Risk aversion refers to reluctance to accept an uncertain payoff rather than a more certain, but possibly lower, expected payoff. According to the Arrow-Pratt measurement, risk aversion as the curvature of utility function reflects a consumer's sensitivity to uncertainty. Since purchasing the house with a mortgage loan reduces the uncertainty that the agent faces regarding how much to save each month in order to be able to own a house, households that are more risk averse should care more about this uncertainty reduction effect of a mortgage, and hence consume more. 
The ratio of risky assets to total liquid assets is commonly used as a proxy in measuring a household's attitude towards risk. In our sample, stock holdings of households comprise their risky assets. Following the two-step process applied by Liao et al. (2014), we first use a tobit model to predict the ratio of risky assets to liquid assets, using the demographic and financial information about households from the UHS database. We then divide the sample into high risk-aversion group and low risk-aversion group, using the median value as the threshold level. For each group, we separately run the consumption regression and compare the coefficient of estimated probability of having a mortgage (Dmortgage). The result exhibited in Table 11 is consistent with our expectations. We find that higher risk aversion leads to a greater positive effect of having a mortgage on consumption. Households that care more about the elimination of future house price uncertainty will consume more after they obtain a mortgage.

\section{Concluding Remarks}

This paper offers the first micro evidence for how mortgage debt impacts household consumption behavior. Utilizing a comprehensive household survey data from China, we show that households with a mortgage consume a higher portion of their income than households without a mortgage. This is in line with the argument that having a mortgage reduces the uncertainty that the household faces regarding how much to save each month in order to be able to own a house, and this reduced uncertainty leads to lower monthly savings for the purpose of buying a house. We also find that among households with a mortgage, those who spend a larger share of their income on mortgage payments spend less of their income on consumption, reflecting the crowding out effect of mortgage payments on household consumption. Furthermore, we show 
that a government policy of decreasing the maximum loan-to-value ratio has a significant impact on the consumption behavior of households.

This current study has some important policy implications. Following the financial crisis, there has been a heated debate in the U.S. and many other countries over some of the government policies that subsidize mortgage borrowing. Examples of these policies include the tax deductibility of mortgage interest payments and implicit government guarantees for mortgages purchased by such government-sponsored agencies as Freddie Mac and Fannie Mae. The current study highlights an important economic impact of these government policies that has been overlooked by earlier studies. There are various arguments for and against government subsidies in mortgage markets. This study adds another argument and shows that policies designed to encourage mortgage borrowing will have an impact on future economic growth through their impact on the consumption and saving rate. Clearly, it is also possible that increased mortgage debt could be associated with improved ability of the borrowers to smooth their consumption over their life cycles. Thus, the current results cannot be used to make any welfare implications about higher mortgage debt. We simply offer evidence on the impact of mortgage debt on household consumption rate. The current study is important for monetary policy as well. Many economies suffer from current account deficit problems, as their saving rates are not sufficiently high enough to finance their high rates of investment and economic growth. Our results indicate that interest rate policy and macroprudential measures can have not only a direct impact on economic growth, but also an indirect impact through their influence on the growth of mortgage credit and its impact on consumption rate. 


\section{Figures and Tables}

Figure 1 Outstanding Mortgage Debt in China

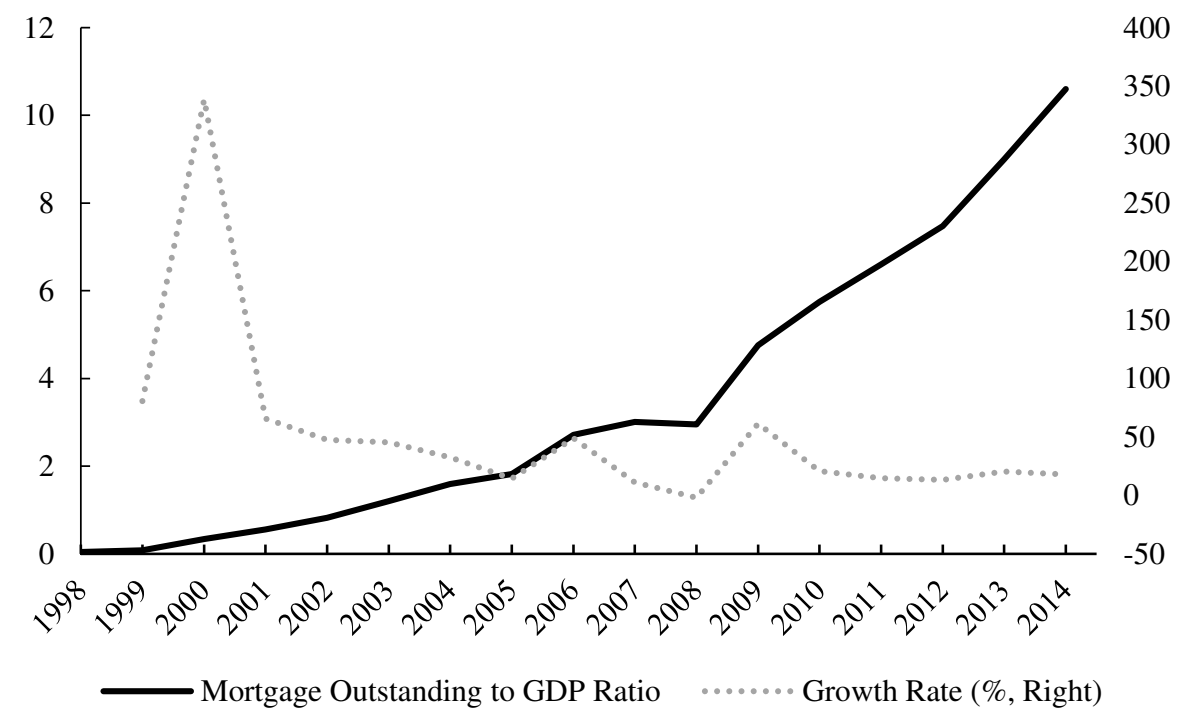

Data source: People's Bank of China and Chinese Bureau of Statistics (1998-2013) 
Figure 2 Household Consumption and Saving Rate in Urban China

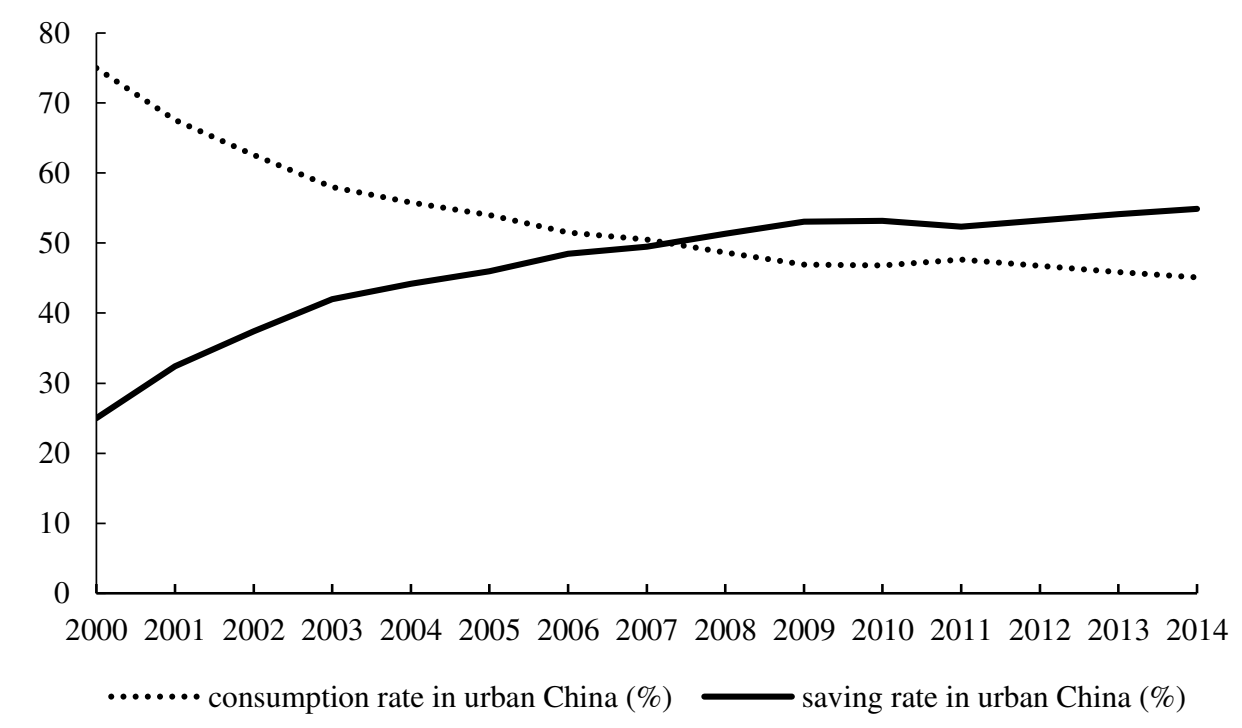

Data Source: Chinese Statistics Bureau (2001-2015) 


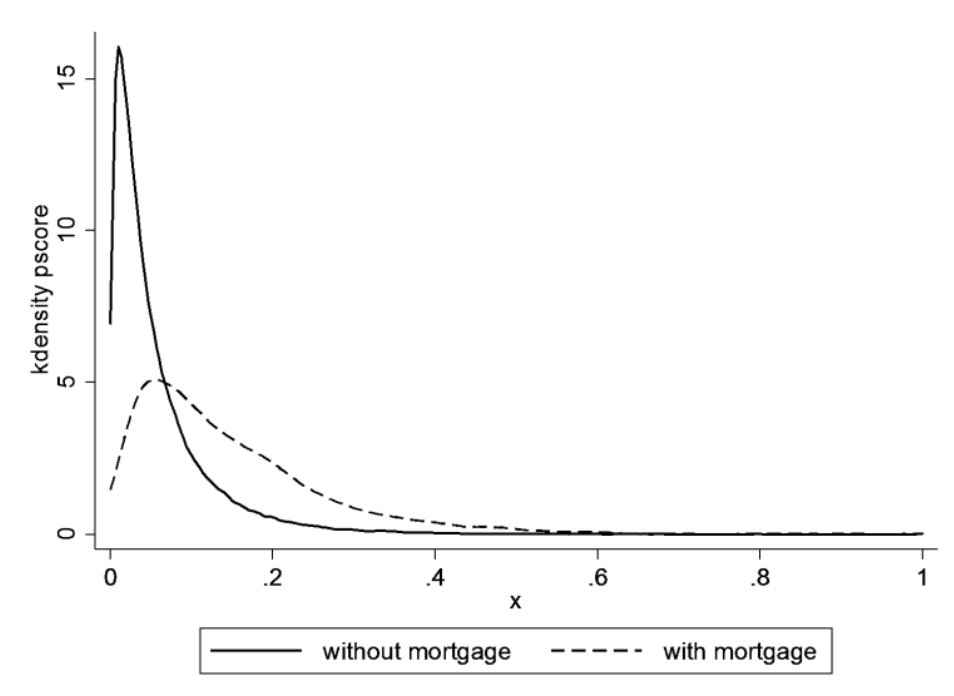

(a) Before PSM

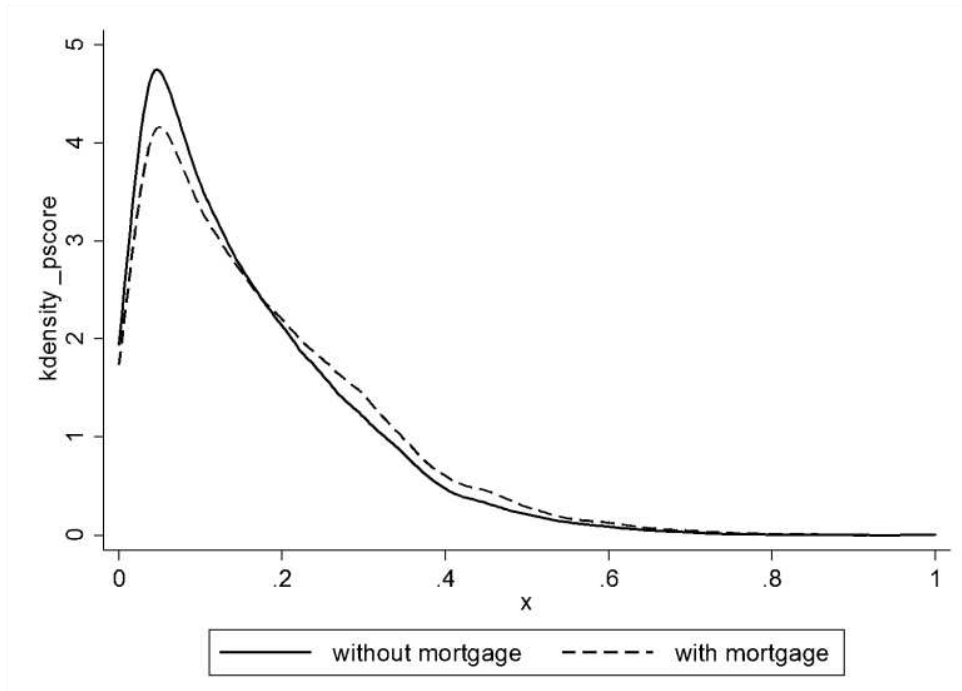

(b) After PSM

Note: Figure (a) demonstrates the kernel density of Propensity Score between households with and without a mortgage before PSM. Figure (b) demonstrates the kernel density of Propensity Score between households with and without a mortgage after PSM. The solid curves denote the possibility of having a mortgage (the Propensity Score) for the group of households without a mortgage, estimated by a probit regression. The dashed line curves denote the possibility of having a mortgage (the Propensity Score) for the households with a mortgage, estimated by a probit regression. Notice that the wide difference in the distribution of the two household groups in Figure (a) is significantly reduced in Figure (b). 
Table 1 Descriptive Statistics of Variables

\begin{tabular}{|c|c|c|c|}
\hline Variable & Descriptions & Mean & Std. dev. \\
\hline totalratio & total consumption to household disposable income ratio & 0.8169137 & 0.4077099 \\
\hline foodratio & food consumption to household disposable income ratio & 0.3338232 & 0.1651546 \\
\hline clothratio & clothing consumption to household disposable income ratio & 0.0788574 & 0.0612889 \\
\hline residentratio & $\begin{array}{l}\text { residential consumption (e.g. decoration costs, water and electricity } \\
\text { fees, property fees) to household disposable income ratio }\end{array}$ & 0.0820764 & 0.1319619 \\
\hline durableratio & $\begin{array}{l}\text { consumption in durable goods (e.g. appliances and furniture) to } \\
\text { household disposable income ratio }\end{array}$ & 0.0434373 & 0.0673032 \\
\hline medicalratio & medical expenditure to household disposable income ratio & 0.0599797 & 0.1214095 \\
\hline transratio & transportation expenditure to household disposable income ratio & 0.0875454 & 0.168218 \\
\hline educateratio & education expenditure to household disposable income ratio & 0.1043637 & 0.1368252 \\
\hline otherratio & other consumption to household disposable income ratio & 0.0268297 & 0.0512705 \\
\hline Dmortgage & dummy variable $=1$ if the household has mortgage payment in that year & 0.0613723 & 0.2400129 \\
\hline mpayratio & the annual mortgage payment to household disposable income ratio & 0.0141774 & 0.0936236 \\
\hline newmortgage & dummy variable $=1$ if the household has acquired mortgage in that year & 0.0051862 & 0.0718286 \\
\hline dispincome & $\begin{array}{l}\text { total household annual disposable income including salary, subsidies, } \\
\text { income from financial assets and unregulated income }\end{array}$ & 32942.39 & 26687.35 \\
\hline$l t i$ & household non-mortgage loan to disposable income ratio & 0.0134491 & 0.106384 \\
\hline child & $\begin{array}{l}\text { dummy variable }=1 \text { if there is at least one person under } 18 \text { years old in } \\
\text { the family }\end{array}$ & 0.631015 & 0.2053736 \\
\hline old & $\begin{array}{l}\text { dummy variable }=1 \text { if there is at least one person over } 60 \text { years old in the } \\
\text { family }\end{array}$ & 0.279294 & 0.448654 \\
\hline asset & total value of assets owned by the household & 152358.1 & 206508.6 \\
\hline married & dummy variable $=1$ if the head of household is married & 0.9390748 & 0.2391941 \\
\hline age & age of the household head & 48.48171 & 11.02875 \\
\hline agesquare & age square of the household head & 2472.109 & 1143.705 \\
\hline hukou & $\begin{array}{l}\text { dummy variable }=1 \text { if the head of household has HUKOU in the } \\
\text { residence city }\end{array}$ & 0.9836981 & 0.1266345 \\
\hline multihouse & dummy variable $=1$ if there are at least two homes owned by the family & 0.082047 & 0.274438 \\
\hline areapp & living area per person in squared meters & 28.92414 & 14.79269 \\
\hline fanggaifang & dummy variable $=1$ if the household lives in a housing-reform house & 0.6278011 & 0.4833931 \\
\hline aveincgrowth & annual growth rate in provincial average income over previous year & 0.1177522 & 0.0284936 \\
\hline hprice & $\begin{array}{l}\text { average selling price of housing units in newly built residential projects } \\
\text { (at province level) }\end{array}$ & 3559.379 & 2490.14 \\
\hline pubsavrate & public saving rate at province level & -0.918646 & 0.6823325 \\
\hline hpinc & annual growth rate in provincial hprice over previous year & 0.1414951 & 0.1096727 \\
\hline interest & 5-year benchmark interest rate set by People's Bank of China (in \%) & 6.408093 & 0.6919267 \\
\hline
\end{tabular}

Note: Data source is the UHS (Urban Household Survey) produced by the National Bureau of Statistics of China (NBSC). Sample size is 109,920 and covers the period 2002-2009. 
Table 2 Minimum Down Payment Requirement Ratio Policies of the People's Bank of China

\begin{tabular}{|c|c|c|c|}
\hline Date & Policy or Agent & Basic Contents & Signal \\
\hline 1995.8 & $\begin{array}{l}\text { People's Bank of China: "Interim Measures for the } \\
\text { Administration of Commercial Banks' } \\
\text { Self-Residing Housing Loans" (PBOC [1995] } \\
\text { No.220) }\end{array}$ & $\begin{array}{l}\text { The minimum mortgage down payment ratio was } \\
30 \% \text { and the maximum term of a mortgage loan } \\
\text { was } 10 \text { years. }\end{array}$ & Start \\
\hline 1999 & $\begin{array}{l}\text { People's Bank of China: "Several opinions about } \\
\text { encouraging consumer loans" (PBOC [1999]) }\end{array}$ & $\begin{array}{l}\text { Reduce the minimum down payment ratio from } \\
30 \% \text { to } 20 \% \text {. }\end{array}$ & Loosen \\
\hline 2005.3 .16 & $\begin{array}{l}\text { People's Bank of China: "Notice about Adjusting } \\
\text { Commercial Bank Housing Credit Policy and } \\
\text { Excess Reserves Deposit Rates" (PBOC [2005] } \\
\text { No.61) }\end{array}$ & $\begin{array}{l}\text { Increase the minimum down payment ratio from } \\
20 \% \text { to } 30 \% \text {. }\end{array}$ & Tighten \\
\hline 2006.5 .29 & $\begin{array}{l}\text { The General Office of the State Council: } \\
\text { "Opinions on Adjusting Housing Supply Structure } \\
\text { to Stabilize Housing Prices" (so-called "Guo Liu } \\
\text { Tiao") (GOSC [2006] No.37) }\end{array}$ & $\begin{array}{l}\text { The minimum proportion of the down payment } \\
\text { of a personal house mortgage shall not be lower } \\
\text { than } 30 \% \text {. However, the minimum } \\
\text { down-payment ratio could still account for } 20 \% \\
\text { for self-residing house purchased with in suite } \\
\text { floor space less than } 90 \mathrm{~m}^{2} \text {. }\end{array}$ & Tighten \\
\hline 2007.9 & $\begin{array}{l}\text { People's Bank of China and China Banking } \\
\text { Regulatory Commission: Notice of Strengthening } \\
\text { the Management of Commercial Property Credit } \\
\text { Loans (CBRC [2007] No. 359). }\end{array}$ & $\begin{array}{l}\text { Raise the minimum down payment ratio to } 40 \% \\
\text { and the minimum mortgage rate to } 110 \% \text { of the } \\
\text { benchmark rate for second mortgages. } \\
\text { Minimum down payment ratio and mortgage } \\
\text { rates are higher for third mortgage loans. }\end{array}$ & Tighten \\
\hline 2008.10 & $\begin{array}{l}\text { People's Bank of China: Notice of Extending the } \\
\text { Downward Movement of Interest Rates for Loans } \\
\text { to Residential Premises of a Commercial Nature } \\
\text { for Individuals in Support of First Time Purchase } \\
\text { of Ordinary Residential Premises by Residents } \\
\text { (PBOC [2008] No. 137). }\end{array}$ & $\begin{array}{l}\text { Reduce the down payment requirements from } \\
30 \% \text { to } 20 \% \text { and adjust the lower limit of the } \\
\text { lending rate for residential properties to } 70 \% \text { of } \\
\text { the benchmark lending rate. Promote preferential } \\
\text { policies for a first-time mortgage in second } \\
\text { house purchasing. }\end{array}$ & Loosen \\
\hline 2010.1 & $\begin{array}{l}\text { State Council: The Circular on Promoting the } \\
\text { Stable and Healthy Development of the Real } \\
\text { Estate Market (SC [2010] No. 4). }\end{array}$ & $\begin{array}{l}\text { The minimum down payment of mortgage loan } \\
\text { for additional residential property shall be } 40 \% \\
\text { of the property value. }\end{array}$ & Tighten \\
\hline 2010.4 & $\begin{array}{l}\text { Ministry of Housing and Urban and Rural } \\
\text { Development, Ministry of Finance, People’s Bank } \\
\text { of China and China Banking Regulatory } \\
\text { Commission: Notice of Issues Relating to } \\
\text { Standardizing Different Residential Mortgage } \\
\text { Loan Policies. (MOHUR and MF [2010] No. 179) }\end{array}$ & $\begin{array}{l}\text { The minimum down payment for the first } \\
\text { purchase of residents will be increased to } 30 \% \\
\text { and all commercial banks shall suspend granting } \\
\text { loans to customers purchasing a third or } \\
\text { subsequent units. For those who purchase a } \\
\text { second residential property, the down payment } \\
\text { shall not be less than } 50 \% \text { of the value. }\end{array}$ & Tighten \\
\hline 2011.1 & $\begin{array}{l}\text { The General Office of the State Council GOSC } \\
\text { [2011] No. } 1\end{array}$ & $\begin{array}{l}\text { Raise down payment for mortgages on second } \\
\text { home to at least } 60 \% \text {. }\end{array}$ & Tighten \\
\hline 2014.9 & $\begin{array}{l}\text { People's Bank of China, the China banking } \\
\text { regulatory commission }\end{array}$ & $\begin{array}{l}\text { For the first housing consumer, the minimum } \\
\text { down payment is adjusted to } 30 \% \text {. }\end{array}$ & Loosen \\
\hline
\end{tabular}


Table 3 Impact of Having a Mortgage on Household Consumption Ratio

\begin{tabular}{|c|c|c|c|c|c|c|c|c|c|c|}
\hline & $\begin{array}{l}\text { (1) } \\
\text { Dmortgage }\end{array}$ & $\begin{array}{l}\text { (2) } \\
\text { totalratio }\end{array}$ & $\begin{array}{l}\text { (3) } \\
\text { foodratio }\end{array}$ & $\begin{array}{l}\text { (4) } \\
\text { clothratio }\end{array}$ & $\begin{array}{l}(5) \\
\text { residentratio }\end{array}$ & $\begin{array}{l}\text { (6) } \\
\text { durableratio }\end{array}$ & $\begin{array}{l}(7) \\
\text { medicalratio }\end{array}$ & $\begin{array}{l}(8) \\
\text { transratio }\end{array}$ & $\begin{array}{l}\text { (9) } \\
\text { educateratio }\end{array}$ & $\begin{array}{l}\text { (10) } \\
\text { otherratio }\end{array}$ \\
\hline \multirow[t]{2}{*}{ Dmortgage } & & $0.441 * * *$ & $0.215^{* * *}$ & $-0.0828 * * *$ & $0.126 * * *$ & $-0.0125^{*}$ & 0.00894 & $0.172 * * *$ & 0.00426 & $0.0106^{* * *}$ \\
\hline & & $(0.0363)$ & $(0.0127)$ & $(0.00528)$ & $(0.0123)$ & $(0.00638)$ & $(0.0112)$ & $(0.0162)$ & $(0.0124)$ & $(0.00346)$ \\
\hline \multirow[t]{2}{*}{ Inpincome } & $0.561 * * *$ & $-0.216^{* * *}$ & $-0.155^{* * *}$ & $-0.00165^{* * *}$ & $-0.0349 * * *$ & $0.00191 * * *$ & $-0.0152 * * *$ & $-0.00349 * *$ & $-0.00858 * * *$ & $0.000901 * * *$ \\
\hline & $(0.0135)$ & $(0.00307)$ & $(0.00108)$ & $(0.000446)$ & $(0.00104)$ & $(0.000539)$ & $(0.000950)$ & $(0.00137)$ & $(0.00105)$ & $(0.000293)$ \\
\hline \multirow[t]{2}{*}{$l t i$} & $0.694 * * *$ & 0.0112 & $-0.0643 * * *$ & $-0.00761 * * *$ & $0.0404 * * *$ & $0.0125 * * *$ & $0.0433 * * *$ & $-0.0109 * *$ & 0.000434 & $-0.00256^{* *}$ \\
\hline & $(0.0416)$ & $(0.0121)$ & $(0.00424)$ & $(0.00176)$ & $(0.00410)$ & $(0.00212)$ & $(0.00374)$ & $(0.00540)$ & $(0.00412)$ & $(0.00115)$ \\
\hline \multirow[t]{2}{*}{ child } & $0.0775 * * *$ & $0.0168 * * *$ & $-0.0255^{* * *}$ & $0.00517 * * *$ & $-0.0129 * * *$ & $-0.00327 * * *$ & $-0.00979 * * *$ & 0.000652 & $0.0618 * * *$ & $0.000598 * *$ \\
\hline & $(0.0178)$ & (0.00309) & $(0.00109)$ & $(0.000450)$ & $(0.00105)$ & $(0.000543)$ & $(0.000958)$ & $(0.00138)$ & $(0.00105)$ & $(0.000295)$ \\
\hline \multirow[t]{2}{*}{ old } & $0.173^{* * *}$ & $-0.0465 * * *$ & $-0.0182 * * *$ & $-0.00485^{* * *}$ & $-0.00332 * * *$ & $0.00161 * * *$ & -0.000512 & -0.000468 & $-0.0204 * * *$ & -0.000401 \\
\hline & $(0.0176)$ & $(0.00299)$ & $(0.00105)$ & $(0.000435)$ & $(0.00102)$ & $(0.000525)$ & $(0.000926)$ & $(0.00134)$ & $(0.00102)$ & $(0.000285)$ \\
\hline \multirow[t]{2}{*}{ Inasset } & $0.0290 * * *$ & 0.000350 & -0.000143 & $0.000779 * * *$ & $-0.00193 * * *$ & $0.000305^{* * *}$ & $0.000487 * * *$ & 0.000151 & $0.000571 * * *$ & $0.000131 * * *$ \\
\hline & $(0.00203)$ & $(0.000363)$ & $(0.000127)$ & $(0.0000528)$ & $(0.000123)$ & $(0.0000637)$ & $(0.000112)$ & $(0.000162)$ & $(0.000124)$ & $(0.0000346)$ \\
\hline \multirow[t]{2}{*}{ married } & 0.165 & $-0.280 * * *$ & $-0.0652 * * *$ & 0.00306 & -0.00502 & -0.00116 & $-0.0949 * * *$ & -0.00309 & $-0.0278 * * *$ & $-0.0860 * * *$ \\
\hline & $(0.146)$ & $(0.0269)$ & $(0.00943)$ & $(0.00391)$ & $(0.00913)$ & $(0.00472)$ & $(0.00832)$ & $(0.0120)$ & $(0.00916)$ & $(0.00256)$ \\
\hline \multirow[t]{2}{*}{ age } & $-0.0461 * * *$ & $0.0133 * * *$ & $0.00608 * * *$ & $-0.00103 * * *$ & $0.00333 * * *$ & -0.000140 & $-0.00453 * * *$ & $0.00256 * * *$ & $0.00701 * * *$ & -0.0000228 \\
\hline & $(0.00485)$ & $(0.000855)$ & $(0.000300)$ & $(0.000124)$ & $(0.000290)$ & $(0.000150)$ & $(0.000265)$ & $(0.000382)$ & $(0.000291)$ & $(0.0000815)$ \\
\hline \multirow[t]{2}{*}{ agesquare } & $0.000222 * * *$ & $-0.000132 * * *$ & $-0.0000519 * * *$ & $-0.00000514^{* * * *}$ & $-0.0000274 * * *$ & 0.000000162 & $0.0000568^{* * *}$ & $-0.0000322 * * *$ & $-0.0000701 * * *$ & $-0.00000177^{*} *$ \\
\hline & $(0.0000507)$ & $(0.00000808)$ & $(0.00000284)$ & $(0.00000118)$ & $(0.00000275)$ & $(0.00000142)$ & $(0.00000250)$ & $(0.00000361)$ & $(0.00000275)$ & $(0.000000770)$ \\
\hline \multirow[t]{2}{*}{ hukou } & $-0.257 * * *$ & $0.0345 * * *$ & $0.0251 * * *$ & $0.00320 * *$ & $-0.0239 * * *$ & $0.00468 * * *$ & 0.00319 & $0.0107 * *$ & $0.00792 * *$ & $0.00349 * * *$ \\
\hline & $(0.0461)$ & $(0.00950)$ & $(0.00334)$ & $(0.00138)$ & $(0.00323)$ & $(0.00167)$ & $(0.00294)$ & $(0.00424)$ & $(0.00324)$ & $(0.000906)$ \\
\hline \multirow[t]{2}{*}{ multihouse } & & $0.0377 * * *$ & $-0.00375^{* *}$ & $-0.00207 * * *$ & $0.0221 * * *$ & $0.00715^{* * *}$ & -0.00138 & $0.00958 * * *$ & $0.00562 * * *$ & 0.000432 \\
\hline & & $(0.00421)$ & $(0.00148)$ & $(0.000613)$ & $(0.00143)$ & $(0.000740)$ & $(0.00131)$ & $(0.00188)$ & $(0.00144)$ & $(0.000402)$ \\
\hline \multirow[t]{2}{*}{ lnareapp } & & 0.00255 & $-0.0214 * * *$ & $0.00790 * * *$ & $0.00834 * * *$ & $0.00304 * * *$ & $-0.00363 * * *$ & $0.00871^{* * *}$ & -0.000667 & 0.000315 \\
\hline & & $(0.00333)$ & $(0.00117)$ & $(0.000485)$ & $(0.00113)$ & $(0.000585)$ & $(0.00103)$ & $(0.00149)$ & $(0.00114)$ & $(0.000318)$ \\
\hline
\end{tabular}




\begin{tabular}{|c|c|c|c|c|c|c|c|c|c|c|}
\hline fanggaifang & & $\begin{array}{l}-0.00337 \\
(0.00282)\end{array}$ & $\begin{array}{l}0.00388 * * * \\
(0.000992)\end{array}$ & $\begin{array}{l}-0.00208 * * * \\
(0.000411)\end{array}$ & $\begin{array}{l}-0.00604 * * * \\
(0.000960)\end{array}$ & $\begin{array}{l}-0.00148 * * * \\
(0.000497)\end{array}$ & $\begin{array}{l}-0.000543 \\
(0.000875)\end{array}$ & $\begin{array}{l}-0.00327 * * * \\
(0.00126)\end{array}$ & $\begin{array}{c}0.00586 * * * \\
(0.000963)\end{array}$ & $\begin{array}{l}0.000305 \\
(0.000269)\end{array}$ \\
\hline aveincgrowth & $\begin{array}{l}-0.136 \\
(0.376)\end{array}$ & $\begin{array}{l}0.169 * * \\
(0.0672)\end{array}$ & $\begin{array}{l}0.149 * * * \\
(0.0236)\end{array}$ & $\begin{array}{l}0.0516 * * * \\
(0.00978)\end{array}$ & $\begin{array}{l}-0.0184 \\
(0.0228)\end{array}$ & $\begin{array}{l}0.0303 * * \\
(0.0118)\end{array}$ & $\begin{array}{l}0.0486 * * \\
(0.0208)\end{array}$ & $\begin{array}{l}-0.00108 \\
(0.0300)\end{array}$ & $\begin{array}{l}-0.101 * * * \\
(0.0229)\end{array}$ & $\begin{array}{l}0.00990 \\
(0.00641)\end{array}$ \\
\hline Inhprice & $\begin{array}{l}0.00969 \\
(0.0815)\end{array}$ & $\begin{array}{l}-0.0928 * * * \\
(0.0136)\end{array}$ & $\begin{array}{l}-0.0221^{* * *} \\
(0.00476)\end{array}$ & $\begin{array}{l}0.00853 * * * \\
(0.00197)\end{array}$ & $\begin{array}{l}-0.0285^{* * *} \\
(0.00461)\end{array}$ & $\begin{array}{l}-0.0147 * * * \\
(0.00238)\end{array}$ & $\begin{array}{l}-0.0116^{* * *} \\
(0.00420)\end{array}$ & $\begin{array}{l}0.00857 \\
(0.00606)\end{array}$ & $\begin{array}{l}-0.0269 * * * \\
(0.00463)\end{array}$ & $\begin{array}{l}-0.00604 * * * \\
(0.00129)\end{array}$ \\
\hline pubsavrate & $\begin{array}{l}0.0321 \\
(0.0963)\end{array}$ & $\begin{array}{l}-0.00221 \\
(0.00828)\end{array}$ & $\begin{array}{l}-0.00965 * * * \\
(0.00291)\end{array}$ & $\begin{array}{l}-0.000879 \\
(0.00121)\end{array}$ & $\begin{array}{l}0.00266 \\
(0.00281)\end{array}$ & $\begin{array}{l}-0.00199 \\
(0.00146)\end{array}$ & $\begin{array}{l}-0.00424 * \\
(0.00257)\end{array}$ & $\begin{array}{l}0.00528 \\
(0.00370)\end{array}$ & $\begin{array}{l}0.00778 * * * \\
(0.00282)\end{array}$ & $\begin{array}{l}-0.00117 \\
(0.000790)\end{array}$ \\
\hline hpinc & $\begin{array}{l}0.0321 \\
(0.0963)\end{array}$ & & & & & & & & & \\
\hline $\begin{array}{l}\text { education and } \\
\text { occupation }\end{array}$ & $\mathrm{Y}$ & $\mathrm{Y}$ & $\mathrm{Y}$ & $\mathrm{Y}$ & $\mathrm{Y}$ & $\mathrm{Y}$ & $\mathrm{Y}$ & $\mathrm{Y}$ & $\mathrm{Y}$ & $\mathrm{Y}$ \\
\hline $\begin{array}{l}\text { year fixed } \\
\text { effect }\end{array}$ & $\mathrm{Y}$ & $\mathrm{Y}$ & $\mathrm{Y}$ & $\mathrm{Y}$ & $\mathrm{Y}$ & $\mathrm{Y}$ & $\mathrm{Y}$ & $\mathrm{Y}$ & $\mathrm{Y}$ & $\mathrm{Y}$ \\
\hline $\begin{array}{l}\text { region fixed } \\
\text { effect }\end{array}$ & $\mathrm{Y}$ & $\mathrm{Y}$ & $\mathrm{Y}$ & $\mathrm{Y}$ & $\mathrm{Y}$ & $\mathrm{Y}$ & $\mathrm{Y}$ & $\mathrm{Y}$ & $\mathrm{Y}$ & $\mathrm{Y}$ \\
\hline _cons & $\begin{array}{l}-5.967 * * * \\
(0.734)\end{array}$ & $\begin{array}{l}3.510 * * * \\
(0.125)\end{array}$ & $\begin{array}{l}1.904 * * * \\
(0.0438)\end{array}$ & $\begin{array}{l}0.0221 \\
(0.0181)\end{array}$ & $\begin{array}{l}0.568 * * * \\
(0.0424)\end{array}$ & $\begin{array}{l}0.146 * * * \\
(0.0219)\end{array}$ & $\begin{array}{l}0.506 * * * \\
(0.0386)\end{array}$ & $\begin{array}{l}-0.0484 \\
(0.0557)\end{array}$ & $\begin{array}{l}0.261 * * * \\
(0.0425)\end{array}$ & $\begin{array}{l}0.152 * * * \\
(0.0119)\end{array}$ \\
\hline $\mathrm{N}$ & 109920 & 109920 & 109920 & 109920 & 109920 & 109920 & 109920 & 109920 & 109920 & 109920 \\
\hline $\mathrm{R}$-sq & & 0.102 & 0.340 & 0.184 & 0.035 & 0.016 & 0.055 & 0.023 & 0.100 & 0.031 \\
\hline
\end{tabular}

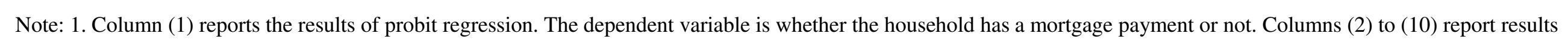

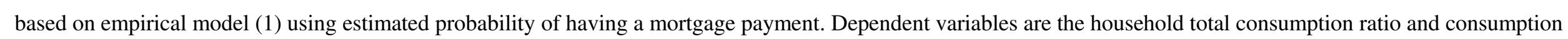
ratios of 8 different subcategories of consumption.

2. Robust standard errors are reported in parentheses: $* * *$ denotes $\mathrm{p}<0.01, * *$ denotes $\mathrm{p}<0.05$, and $*$ denotes $\mathrm{p}<0.1$.

3. In denotes logarithm of the variable. 
Table 4 Impact of Mortgage Payment Ratio on Household Consumption Ratio

\begin{tabular}{|c|c|c|c|c|c|c|c|c|c|c|}
\hline & $\begin{array}{l}\text { (1) } \\
\text { Dmortgage }\end{array}$ & $\begin{array}{l}(2) \\
\text { totalratio }\end{array}$ & $\begin{array}{l}\text { (3) } \\
\text { foodratio }\end{array}$ & $\begin{array}{l}(4) \\
\text { clothratio }\end{array}$ & $\begin{array}{l}(5) \\
\text { residentratio }\end{array}$ & $\begin{array}{l}\text { (6) } \\
\text { durableratio }\end{array}$ & $\begin{array}{l}(7) \\
\text { medicalratio }\end{array}$ & $\begin{array}{l}(8) \\
\text { transratio }\end{array}$ & $\begin{array}{l}\text { (9) } \\
\text { educateratio }\end{array}$ & $\begin{array}{l}(10) \\
\text { otherratio }\end{array}$ \\
\hline mpayratio & & $\begin{array}{l}-0.237 * * * \\
(0.0384)\end{array}$ & $\begin{array}{l}-0.0616^{* * *} \\
(0.00873)\end{array}$ & $\begin{array}{l}-0.0333 * * * \\
(0.00461)\end{array}$ & $\begin{array}{l}0.00954 \\
(0.0205)\end{array}$ & $\begin{array}{l}-0.0174 * \\
(0.00903)\end{array}$ & $\begin{array}{l}-0.0358 * * * \\
(0.00671)\end{array}$ & $\begin{array}{l}-0.0465 * * * \\
(0.0180)\end{array}$ & $\begin{array}{l}-0.0372 * * * \\
(0.00907)\end{array}$ & $\begin{array}{l}-0.0150 * * * \\
(0.00297)\end{array}$ \\
\hline Inpincome & $\begin{array}{l}0.561 * * * \\
(0.0135)\end{array}$ & $\begin{array}{l}-0.0279 \\
(0.0513)\end{array}$ & $\begin{array}{l}-0.0680 * * * \\
(0.0117)\end{array}$ & $\begin{array}{l}-0.0108 * \\
(0.00616)\end{array}$ & $\begin{array}{l}0.114 * * * \\
(0.0273)\end{array}$ & $\begin{array}{l}-0.0226^{*} \\
(0.0121)\end{array}$ & $\begin{array}{l}-0.0421 * * * \\
(0.00896)\end{array}$ & $\begin{array}{l}0.0250 \\
(0.0240)\end{array}$ & $\begin{array}{l}-0.0236^{*} \\
(0.0121)\end{array}$ & $\begin{array}{l}0.000123 \\
(0.00397)\end{array}$ \\
\hline$l t i$ & $\begin{array}{l}0.694 * * * \\
(0.0416)\end{array}$ & $\begin{array}{l}0.240 * * * \\
(0.0429)\end{array}$ & $\begin{array}{l}0.0219 * * \\
(0.00977)\end{array}$ & $\begin{array}{l}-0.00606 \\
(0.00516)\end{array}$ & $\begin{array}{l}0.224 * * * \\
(0.0229)\end{array}$ & $\begin{array}{l}0.00349 \\
(0.0101)\end{array}$ & $\begin{array}{l}-0.0126^{*} \\
(0.00750)\end{array}$ & $\begin{array}{l}0.0192 \\
(0.0201)\end{array}$ & $\begin{array}{l}-0.00877 \\
(0.0101)\end{array}$ & $\begin{array}{l}-0.00119 \\
(0.00332)\end{array}$ \\
\hline child & $\begin{array}{l}0.0775 * * * \\
(0.0178)\end{array}$ & $\begin{array}{l}0.0164 \\
(0.0158)\end{array}$ & $\begin{array}{l}-0.0186 * * * \\
(0.00359)\end{array}$ & $\begin{array}{l}0.00202 \\
(0.00190)\end{array}$ & $\begin{array}{l}0.0168 * * \\
(0.00842)\end{array}$ & $\begin{array}{l}-0.00582 \\
(0.00371)\end{array}$ & $\begin{array}{l}-0.0133 * * * \\
(0.00276)\end{array}$ & $\begin{array}{l}0.00273 \\
(0.00740)\end{array}$ & $\begin{array}{l}0.0361 * * * \\
(0.00373)\end{array}$ & $\begin{array}{l}-0.00356 * * * \\
(0.00122)\end{array}$ \\
\hline old & $\begin{array}{l}0.173 * * * \\
(0.0176)\end{array}$ & $\begin{array}{l}0.000595 \\
(0.0216)\end{array}$ & $\begin{array}{l}0.00191 \\
(0.00491)\end{array}$ & $\begin{array}{l}-0.0120 * * * \\
(0.00259)\end{array}$ & $\begin{array}{l}0.0432 * * * \\
(0.0115)\end{array}$ & $\begin{array}{l}-0.00694 \\
(0.00508)\end{array}$ & $\begin{array}{l}-0.00537 \\
(0.00377)\end{array}$ & $\begin{array}{l}0.0100 \\
(0.0101)\end{array}$ & $\begin{array}{l}-0.0278 * * * \\
(0.00510)\end{array}$ & $\begin{array}{l}-0.00243 \\
(0.00167)\end{array}$ \\
\hline lnasset & $\begin{array}{l}0.0290 * * * \\
(0.00203)\end{array}$ & $\begin{array}{l}0.00367 \\
(0.00337)\end{array}$ & $\begin{array}{l}0.00195 * * \\
(0.000767)\end{array}$ & $\begin{array}{l}0.000365 \\
(0.000405)\end{array}$ & $\begin{array}{l}0.00376^{* *} \\
(0.00180)\end{array}$ & $\begin{array}{l}-0.00183 * * \\
(0.000793)\end{array}$ & $\begin{array}{l}-0.00101 * \\
(0.000589)\end{array}$ & $\begin{array}{l}0.000557 \\
(0.00158)\end{array}$ & $\begin{array}{l}-0.000202 \\
(0.000796)\end{array}$ & $\begin{array}{l}0.0000927 \\
(0.000261)\end{array}$ \\
\hline married & $\begin{array}{l}0.165 \\
(0.146)\end{array}$ & $\begin{array}{l}-0.00391 \\
(0.111)\end{array}$ & $\begin{array}{l}0.0142 \\
(0.0252)\end{array}$ & $\begin{array}{l}-0.00212 \\
(0.0133)\end{array}$ & $\begin{array}{l}0.0444 \\
(0.0591)\end{array}$ & $\begin{array}{l}-0.00775 \\
(0.0261)\end{array}$ & $\begin{array}{l}-0.0438^{* *} \\
(0.0194)\end{array}$ & $\begin{array}{l}0.0205 \\
(0.0519)\end{array}$ & $\begin{array}{l}0.0177 \\
(0.0262)\end{array}$ & $\begin{array}{l}-0.0470 * * * \\
(0.00858)\end{array}$ \\
\hline age & $\begin{array}{l}-0.0461 * * * \\
(0.00485)\end{array}$ & $\begin{array}{l}0.000777 \\
(0.00571)\end{array}$ & $\begin{array}{l}-0.000359 \\
(0.00130)\end{array}$ & $\begin{array}{l}0.00105 \\
(0.000686)\end{array}$ & $\begin{array}{l}-0.00714 * * \\
(0.00305)\end{array}$ & $\begin{array}{l}0.00322 * * \\
(0.00134)\end{array}$ & $\begin{array}{l}-0.00299 * * * \\
(0.000998)\end{array}$ & $\begin{array}{l}-0.00222 \\
(0.00268)\end{array}$ & $\begin{array}{l}0.00866^{* * *} \\
(0.00135)\end{array}$ & $\begin{array}{l}0.000552 \\
(0.000442)\end{array}$ \\
\hline agesquare & $\begin{array}{l}0.000222 * * * \\
(0.0000507)\end{array}$ & $\begin{array}{l}-0.0000763 \\
(0.0000482)\end{array}$ & $\begin{array}{l}-0.00000828 \\
(0.0000110)\end{array}$ & $\begin{array}{l}-0.0000220 * * * \\
(0.00000579)\end{array}$ & $\begin{array}{l}0.0000175 \\
(0.0000257)\end{array}$ & $\begin{array}{l}-0.0000257 * * \\
(0.0000113)\end{array}$ & $\begin{array}{l}0.0000495 * * * \\
(0.00000842)\end{array}$ & $\begin{array}{l}0.00000575 \\
(0.0000226)\end{array}$ & $\begin{array}{l}-0.0000851 * * * \\
(0.0000114)\end{array}$ & $\begin{array}{l}-0.00000794 * * \\
(0.00000373)\end{array}$ \\
\hline hukou & $\begin{array}{l}-0.257 * * * \\
(0.0461)\end{array}$ & $\begin{array}{l}0.00553 \\
(0.0373)\end{array}$ & $\begin{array}{l}-0.00226 \\
(0.00847)\end{array}$ & $\begin{array}{l}0.00376 \\
(0.00447)\end{array}$ & $\begin{array}{l}-0.0650^{* * *} \\
(0.0199)\end{array}$ & $\begin{array}{l}0.0179 * * \\
(0.00876)\end{array}$ & $\begin{array}{l}0.0116^{*} \\
(0.00651)\end{array}$ & $\begin{array}{l}0.0293 * \\
(0.0175)\end{array}$ & $\begin{array}{l}0.00873 \\
(0.00881)\end{array}$ & $\begin{array}{l}0.00141 \\
(0.00288)\end{array}$ \\
\hline multihouse & & $\begin{array}{l}0.0428 * * * \\
(0.0127)\end{array}$ & $\begin{array}{l}-0.00413 \\
(0.00290)\end{array}$ & $\begin{array}{l}-0.00401 * * * \\
(0.00153)\end{array}$ & $\begin{array}{l}0.0386 * * * \\
(0.00680)\end{array}$ & $\begin{array}{l}0.0142 * * * \\
(0.00300)\end{array}$ & $\begin{array}{l}-0.00381 * \\
(0.00223)\end{array}$ & $\begin{array}{l}-0.00195 \\
(0.00598)\end{array}$ & $\begin{array}{l}0.00442 \\
(0.00301)\end{array}$ & $\begin{array}{l}-0.000510 \\
(0.000987)\end{array}$ \\
\hline lnareapp & & $\begin{array}{l}0.0112 \\
(0.0157)\end{array}$ & $\begin{array}{l}-0.0142 * * * \\
(0.00357)\end{array}$ & $\begin{array}{l}0.00938 * * * \\
(0.00188)\end{array}$ & $\begin{array}{l}0.00104 \\
(0.00837)\end{array}$ & $\begin{array}{l}-0.00582 \\
(0.00369)\end{array}$ & $\begin{array}{l}0.00152 \\
(0.00274)\end{array}$ & $\begin{array}{l}0.0127 * \\
(0.00736)\end{array}$ & $\begin{array}{l}0.00466 \\
(0.00371)\end{array}$ & $\begin{array}{l}0.00194 \\
(0.00121)\end{array}$ \\
\hline fanggaifang & & $\begin{array}{l}0.0166 \\
(0.0121)\end{array}$ & $\begin{array}{l}0.000323 \\
(0.00274)\end{array}$ & $\begin{array}{l}0.00287 * * \\
(0.00145)\end{array}$ & $\begin{array}{l}0.00395 \\
(0.00643)\end{array}$ & $\begin{array}{l}0.00373 \\
(0.00284)\end{array}$ & $\begin{array}{l}0.00177 \\
(0.00211)\end{array}$ & $\begin{array}{l}-0.00417 \\
(0.00566)\end{array}$ & $\begin{array}{l}0.00791 * * * \\
(0.00285)\end{array}$ & $\begin{array}{l}0.000247 \\
(0.000934)\end{array}$ \\
\hline
\end{tabular}




\begin{tabular}{|c|c|c|c|c|c|c|c|c|c|c|}
\hline aveincgrowth & $\begin{array}{l}-0.136 \\
(0.376)\end{array}$ & $\begin{array}{l}0.273 \\
(0.288)\end{array}$ & $\begin{array}{l}0.146 * * \\
(0.0655)\end{array}$ & $\begin{array}{l}0.0343 \\
(0.0346)\end{array}$ & $\begin{array}{l}0.0365 \\
(0.154)\end{array}$ & $\begin{array}{l}0.167 * * \\
(0.0677)\end{array}$ & $\begin{array}{l}0.0288 \\
(0.0503)\end{array}$ & $\begin{array}{l}-0.164 \\
(0.135)\end{array}$ & $\begin{array}{l}0.0290 \\
(0.0681)\end{array}$ & $\begin{array}{l}-0.00505 \\
(0.0223)\end{array}$ \\
\hline Inhprice & $\begin{array}{l}0.00969 \\
(0.0815)\end{array}$ & $\begin{array}{l}-0.0796 \\
(0.0611)\end{array}$ & $\begin{array}{l}-0.0403 * * * \\
(0.0139)\end{array}$ & $\begin{array}{l}0.0154 * * \\
(0.00734)\end{array}$ & $\begin{array}{l}-0.0497 \\
(0.0326)\end{array}$ & $\begin{array}{l}-0.0268^{*} \\
(0.0144)\end{array}$ & $\begin{array}{l}-0.0120 \\
(0.0107)\end{array}$ & $\begin{array}{l}0.0546^{*} \\
(0.0286)\end{array}$ & $\begin{array}{l}-0.0111 \\
(0.0144)\end{array}$ & $\begin{array}{l}-0.00969 * * \\
(0.00473)\end{array}$ \\
\hline pubsavrate & & $\begin{array}{l}-0.0904 * * \\
(0.0362)\end{array}$ & $\begin{array}{l}0.00363 \\
(0.00824)\end{array}$ & $\begin{array}{l}-0.0132 * * * \\
(0.00435)\end{array}$ & $\begin{array}{l}-0.0346^{*} \\
(0.0193)\end{array}$ & $\begin{array}{l}-0.00488 \\
(0.00852)\end{array}$ & $\begin{array}{l}-0.00923 \\
(0.00633)\end{array}$ & $\begin{array}{l}-0.0125 \\
(0.0170)\end{array}$ & $\begin{array}{l}-0.0201 * * \\
(0.00856)\end{array}$ & $\begin{array}{l}0.000463 \\
(0.00280)\end{array}$ \\
\hline currate & $\begin{array}{l}0.0321 \\
(0.0963)\end{array}$ & & & & & & & & & \\
\hline lambdamort & & $\begin{array}{l}0.209 * \\
(0.109)\end{array}$ & $\begin{array}{l}0.0658 * * * \\
(0.0249)\end{array}$ & $\begin{array}{l}-0.00147 \\
(0.0131)\end{array}$ & $\begin{array}{l}0.276 * * * \\
(0.0583)\end{array}$ & $\begin{array}{l}-0.0498^{*} \\
(0.0257)\end{array}$ & $\begin{array}{l}-0.0590 * * * \\
(0.0191)\end{array}$ & $\begin{array}{l}0.0170 \\
(0.0512)\end{array}$ & $\begin{array}{l}-0.0354 \\
(0.0258)\end{array}$ & $\begin{array}{l}-0.00384 \\
(0.00846)\end{array}$ \\
\hline education and occupation & $\mathrm{Y}$ & $\mathrm{Y}$ & $\mathrm{Y}$ & $\mathrm{Y}$ & $\mathrm{Y}$ & $\mathrm{Y}$ & $\mathrm{Y}$ & $\mathrm{Y}$ & $\mathrm{Y}$ & $\mathrm{Y}$ \\
\hline year fixed effect & $\mathrm{Y}$ & $\mathrm{Y}$ & $\mathrm{Y}$ & $\mathrm{Y}$ & $\mathrm{Y}$ & $\mathrm{Y}$ & $\mathrm{Y}$ & $\mathrm{Y}$ & $\mathrm{Y}$ & $\mathrm{Y}$ \\
\hline region fixed effect & $\mathrm{Y}$ & $\mathrm{Y}$ & $\mathrm{Y}$ & $\mathrm{Y}$ & $\mathrm{Y}$ & $\mathrm{Y}$ & $\mathrm{Y}$ & $\mathrm{Y}$ & $\mathrm{Y}$ & $\mathrm{Y}$ \\
\hline _cons & $\begin{array}{l}-5.967 * * * \\
(0.734)\end{array}$ & $\begin{array}{l}1.300 \\
(0.833)\end{array}$ & $\begin{array}{l}1.148^{* * *} \\
(0.189)\end{array}$ & $\begin{array}{l}-0.00651 \\
(0.100)\end{array}$ & $\begin{array}{l}-0.931 * * \\
(0.444)\end{array}$ & $\begin{array}{l}0.573 * * * \\
(0.196)\end{array}$ & $\begin{array}{l}0.771 * * * \\
(0.146)\end{array}$ & $\begin{array}{l}-0.657^{*} \\
(0.391)\end{array}$ & $\begin{array}{l}0.246 \\
(0.197)\end{array}$ & $\begin{array}{l}0.157 * * \\
(0.0645)\end{array}$ \\
\hline $\mathrm{N}$ & 109920 & 6885 & 6885 & 6885 & 6885 & 6885 & 6885 & 6885 & 6885 & 6885 \\
\hline R-sq & & 0.057 & 0.309 & 0.169 & 0.042 & 0.025 & 0.060 & 0.031 & 0.095 & 0.036 \\
\hline
\end{tabular}

Note: 1. Column (1) reports the results of Heckman first stage using probit regression. The dependent variable is whether the household has a mortgage payment or not. Columns (2) to (10) report results based on empirical model (2) including the inverse Mills ratio estimated in Column (1). Dependent variables are the household total consumption ratio and consumption ratios of 8 different subcategories of consumption.

2. Robust standard errors are reported in parentheses: *** denotes $\mathrm{p}<0.01$, ** denotes $\mathrm{p}<0.05$, and $*$ denotes $\mathrm{p}<0.1$.

3. In denotes logarithm of the variable.

4. lambdamort denotes the inverse Mills ratio calculated by the Heckman process to control for the selection bias of mortgage acquisition. 
Table 5 Impact of Obtaining a New Mortgage on Household Consumption Ratio

\begin{tabular}{|c|c|c|c|c|c|c|c|c|c|}
\hline & $\begin{array}{l}\text { (1) } \\
\text { totalratio }\end{array}$ & $\begin{array}{l}\text { (2) } \\
\text { foodratio }\end{array}$ & $\begin{array}{l}\text { (3) } \\
\text { clothratio }\end{array}$ & $\begin{array}{l}\text { (4) } \\
\text { residentratio }\end{array}$ & $\begin{array}{l}\text { (5) } \\
\text { durableratio }\end{array}$ & $\begin{array}{l}\text { (6) } \\
\text { medicalratio }\end{array}$ & $\begin{array}{l}(7) \\
\text { transratio }\end{array}$ & $\begin{array}{l}\text { (8) } \\
\text { educateratio }\end{array}$ & $\begin{array}{l}\text { (9) } \\
\text { otherratio }\end{array}$ \\
\hline \multirow[t]{2}{*}{ mpayratio } & $-0.225 * * *$ & $-0.0617 * * *$ & $-0.0344 * * *$ & 0.0178 & -0.00954 & $-0.0312 * * *$ & $-0.0531 * * *$ & $-0.0370 * * *$ & $-0.0158 * * *$ \\
\hline & $(0.0398)$ & $(0.00919)$ & $(0.00485)$ & $(0.0207)$ & $(0.00924)$ & $(0.00703)$ & $(0.0191)$ & $(0.00956)$ & $(0.00315)$ \\
\hline \multirow[t]{2}{*}{ mpayratio $\times$ newmortgage } & 0.234 & 0.0123 & 0.0161 & 0.0789 & 0.00660 & -0.0138 & $0.139 *$ & -0.00922 & 0.00438 \\
\hline & $(0.148)$ & $(0.0342)$ & $(0.0180)$ & $(0.0771)$ & $(0.0344)$ & $(0.0262)$ & $(0.0709)$ & $(0.0356)$ & $(0.0117)$ \\
\hline \multirow[t]{2}{*}{ newmortgage } & $0.128 * * *$ & -0.00838 & $-0.0114 * * *$ & $0.146 * * *$ & $0.0306^{* * *}$ & 0.000300 & -0.0256 & -0.00203 & -0.000744 \\
\hline & $(0.0332)$ & $(0.00766)$ & $(0.00404)$ & $(0.0173)$ & $(0.00770)$ & $(0.00586)$ & $(0.0159)$ & $(0.00797)$ & $(0.00262)$ \\
\hline \multirow[t]{2}{*}{ lnpincome } & 0.0213 & $-0.0482 *$ & $-0.0457 * * *$ & -0.0384 & 0.0133 & $-0.0530 * * *$ & $0.198 * * *$ & -0.0106 & 0.00553 \\
\hline & $(0.110)$ & $(0.0253)$ & $(0.0133)$ & $(0.0570)$ & $(0.0254)$ & $(0.0193)$ & $(0.0524)$ & $(0.0263)$ & $(0.00866)$ \\
\hline \multirow[t]{2}{*}{$l t i$} & $0.245^{*}$ & 0.0443 & $-0.0504 * * *$ & -0.0340 & $0.0499 *$ & -0.0243 & $0.244 * * *$ & 0.00881 & 0.00629 \\
\hline & $(0.129)$ & $(0.0298)$ & $(0.0157)$ & $(0.0673)$ & $(0.0300)$ & $(0.0228)$ & $(0.0619)$ & $(0.0311)$ & $(0.0102)$ \\
\hline \multirow[t]{2}{*}{ child } & 0.0259 & $-0.0151 * * *$ & -0.00296 & -0.00325 & -0.000467 & $-0.0144 * * *$ & $0.0273 * * *$ & $0.0377 * * *$ & $-0.00291^{*}$ \\
\hline & $(0.0210)$ & $(0.00484)$ & $(0.00255)$ & $(0.0109)$ & $(0.00487)$ & $(0.00370)$ & $(0.0100)$ & $(0.00504)$ & $(0.00166)$ \\
\hline \multirow[t]{2}{*}{ old } & 0.0113 & 0.00648 & $-0.0230 * * *$ & -0.00867 & 0.00370 & -0.00793 & $0.0644 * * *$ & $-0.0231 * * *$ & -0.000551 \\
\hline & $(0.0372)$ & $(0.00857)$ & $(0.00452)$ & $(0.0193)$ & $(0.00862)$ & $(0.00656)$ & $(0.0178)$ & $(0.00892)$ & $(0.00294)$ \\
\hline \multirow[t]{2}{*}{ lnasset } & 0.00686 & $0.00270^{*}$ & $-0.00172 * *$ & -0.00386 & 0.000506 & -0.00142 & $0.00957 * * *$ & 0.000657 & 0.000437 \\
\hline & $(0.00617)$ & $(0.00142)$ & $(0.000751)$ & $(0.00321)$ & $(0.00143)$ & $(0.00109)$ & $(0.00295)$ & $(0.00148)$ & $(0.000488)$ \\
\hline \multirow[t]{2}{*}{ married } & 0.00220 & 0.0200 & -0.0114 & -0.00767 & 0.00184 & $-0.0468 * *$ & 0.0693 & 0.0223 & $-0.0454 * * *$ \\
\hline & $(0.112)$ & $(0.0259)$ & $(0.0137)$ & $(0.0585)$ & $(0.0261)$ & $(0.0198)$ & $(0.0538)$ & $(0.0270)$ & $(0.00889)$ \\
\hline \multirow[t]{2}{*}{ age } & -0.00198 & -0.00186 & $0.00375 * * *$ & 0.00462 & 0.000578 & -0.00168 & $-0.0155^{* * *}$ & $0.00798 * * *$ & 0.000148 \\
\hline & $(0.00946)$ & $(0.00218)$ & $(0.00115)$ & $(0.00492)$ & $(0.00220)$ & $(0.00167)$ & $(0.00453)$ & $(0.00227)$ & $(0.000748)$ \\
\hline \multirow[t]{2}{*}{ agesquare } & -0.0000693 & -0.00000175 & $-0.0000339 * * *$ & -0.0000338 & -0.0000139 & $0.0000410 * * *$ & $0.0000626^{* *}$ & $-0.0000834 * * *$ & -0.00000631 \\
\hline & $(0.0000586)$ & $(0.0000135)$ & $(0.00000713)$ & $(0.0000305)$ & $(0.0000136)$ & $(0.0000103)$ & $(0.0000281)$ & $(0.0000141)$ & $(0.00000463)$ \\
\hline \multirow[t]{2}{*}{ hukou } & -0.0117 & -0.00934 & $0.0195 * * *$ & 0.000731 & 0.00329 & $0.0175^{*}$ & $-0.0479^{*}$ & 0.00530 & -0.000879 \\
\hline & $(0.0569)$ & $(0.0131)$ & $(0.00693)$ & $(0.0296)$ & $(0.0132)$ & $(0.0100)$ & $(0.0272)$ & $(0.0137)$ & $(0.00450)$ \\
\hline \multirow[t]{2}{*}{ multihouse } & $0.0330 * * *$ & -0.00464 & $-0.00370 * *$ & $0.0322 * * *$ & $0.0123 * * *$ & $-0.00421 *$ & -0.00302 & 0.00451 & -0.000440 \\
\hline & $(0.0127)$ & $(0.00293)$ & $(0.00154)$ & $(0.00660)$ & $(0.00294)$ & $(0.00224)$ & $(0.00607)$ & $(0.00305)$ & $(0.00100)$ \\
\hline
\end{tabular}




\begin{tabular}{|c|c|c|c|c|c|c|c|c|c|}
\hline \multirow[t]{2}{*}{ lnareapp } & 0.0102 & $-0.0136 * * *$ & $0.00970 * * *$ & 0.00125 & $-0.00730 * *$ & -0.0000503 & $0.0150 * *$ & 0.00312 & $0.00213^{*}$ \\
\hline & $(0.0158)$ & $(0.00366)$ & $(0.00193)$ & $(0.00824)$ & $(0.00368)$ & $(0.00280)$ & $(0.00758)$ & $(0.00381)$ & $(0.00125)$ \\
\hline \multirow[t]{2}{*}{ fanggaifang } & $0.0265 * *$ & 0.00297 & $0.00285^{*}$ & 0.00995 & $0.00493 *$ & 0.00208 & -0.00470 & $0.00795 * * *$ & 0.000494 \\
\hline & $(0.0125)$ & $(0.00288)$ & $(0.00152)$ & $(0.00649)$ & $(0.00289)$ & $(0.00220)$ & $(0.00597)$ & $(0.00299)$ & $(0.000986)$ \\
\hline \multirow[t]{2}{*}{ aveincgrowth } & 0.385 & $0.157 * *$ & 0.0319 & 0.129 & $0.193 * * *$ & 0.0124 & -0.165 & 0.0346 & -0.00905 \\
\hline & $(0.288)$ & $(0.0664)$ & $(0.0350)$ & $(0.150)$ & $(0.0668)$ & $(0.0508)$ & $(0.138)$ & $(0.0691)$ & $(0.0227)$ \\
\hline \multirow[t]{2}{*}{ lnhprice } & -0.0736 & $-0.0330 * *$ & $0.0135^{*}$ & -0.0501 & $-0.0240 *$ & -0.0133 & $0.0558 *$ & -0.0119 & $-0.0106 * *$ \\
\hline & $(0.0610)$ & $(0.0141)$ & $(0.00742)$ & $(0.0317)$ & $(0.0141)$ & $(0.0108)$ & $(0.0292)$ & $(0.0146)$ & $(0.00482)$ \\
\hline \multirow[t]{2}{*}{ pubsavrate } & $-0.0791 * *$ & 0.00422 & $-0.0115 * * *$ & -0.0293 & -0.00201 & -0.0102 & -0.0107 & $-0.0198 * *$ & 0.0000920 \\
\hline & $(0.0362)$ & $(0.00834)$ & $(0.00440)$ & $(0.0188)$ & $(0.00839)$ & $(0.00638)$ & $(0.0173)$ & $(0.00869)$ & $(0.00286)$ \\
\hline \multirow[t]{2}{*}{ lambdamort } & 0.311 & $0.107^{*}$ & $-0.0796 * * *$ & -0.0580 & 0.0278 & $-0.0844 * *$ & $0.398 * * *$ & -0.00743 & 0.00833 \\
\hline & $(0.239)$ & $(0.0551)$ & $(0.0291)$ & $(0.124)$ & $(0.0554)$ & $(0.0422)$ & $(0.114)$ & $(0.0574)$ & $(0.0189)$ \\
\hline education and occupation & $\mathrm{Y}$ & $\mathrm{Y}$ & $\mathrm{Y}$ & $\mathrm{Y}$ & $\mathrm{Y}$ & $\mathrm{Y}$ & $\mathrm{Y}$ & $\mathrm{Y}$ & $\mathrm{Y}$ \\
\hline year fixed effect & $\mathrm{Y}$ & $\mathrm{Y}$ & $\mathrm{Y}$ & $\mathrm{Y}$ & $\mathrm{Y}$ & $\mathrm{Y}$ & $\mathrm{Y}$ & $\mathrm{Y}$ & $\mathrm{Y}$ \\
\hline region fixed effect & $\mathrm{Y}$ & $\mathrm{Y}$ & $\mathrm{Y}$ & $\mathrm{Y}$ & $\mathrm{Y}$ & $\mathrm{Y}$ & $\mathrm{Y}$ & $\mathrm{Y}$ & $\mathrm{Y}$ \\
\hline \multirow[t]{2}{*}{ cons } & 0.597 & $0.845^{* *}$ & $0.444 * *$ & 0.910 & 0.103 & $0.912 * * *$ & $-2.800 * * *$ & 0.0859 & 0.0963 \\
\hline & (1.466) & $(0.338)$ & $(0.178)$ & $(0.763)$ & $(0.340)$ & $(0.259)$ & $(0.701)$ & $(0.352)$ & $(0.116)$ \\
\hline $\mathrm{N}$ & 6741 & 6741 & 6741 & 6741 & 6741 & 6741 & 6741 & 6741 & 6741 \\
\hline R-sq & 0.059 & 0.308 & 0.170 & 0.056 & 0.034 & 0.059 & 0.034 & 0.095 & 0.035 \\
\hline
\end{tabular}

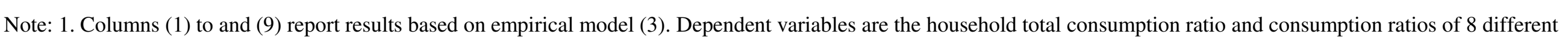
subcategories of consumption.

2. Robust standard errors are reported in parentheses: $* * *$ denotes $\mathrm{p}<0.01$, $* *$ denotes $\mathrm{p}<0.05$, and $*$ denotes $\mathrm{p}<0.1$.

3. In denotes logarithm of the variable.

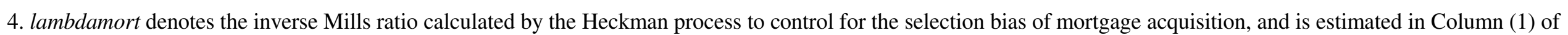
Table 4. 
Table 6 Minimum Down Payment Policy and the Impact of Having a Mortgage on Consumption Ratio

\begin{tabular}{|c|c|c|c|c|c|c|c|c|c|}
\hline & $\begin{array}{l}\text { (1) } \\
\text { totalratio }\end{array}$ & $\begin{array}{l}(2) \\
\text { foodratio }\end{array}$ & $\begin{array}{l}\text { (3) } \\
\text { clothratio }\end{array}$ & $\begin{array}{l}\text { (4) } \\
\text { residentratio }\end{array}$ & $\begin{array}{l}\text { (5) } \\
\text { durableratio }\end{array}$ & $\begin{array}{l}\text { (6) } \\
\text { medicalratio }\end{array}$ & $\begin{array}{l}\text { (7) } \\
\text { transratio }\end{array}$ & $\begin{array}{l}\text { (8) } \\
\text { educateratio }\end{array}$ & $\begin{array}{l}\text { (9) } \\
\text { otherratio }\end{array}$ \\
\hline \multirow[t]{2}{*}{ Dmortgage } & $0.421 * * *$ & $0.220 * * *$ & $-0.0874 * * *$ & $0.129 * * *$ & $-0.0193 * * *$ & $0.0210^{*}$ & $0.150 * * *$ & -0.000300 & $0.00844 * *$ \\
\hline & $(0.0387)$ & $(0.0136)$ & $(0.00563)$ & $(0.0131)$ & $(0.00680)$ & $(0.0120)$ & $(0.0173)$ & $(0.0132)$ & $(0.00369)$ \\
\hline \multirow[t]{2}{*}{ Dmortgage $\times$ tighten } & -0.0263 & $-0.0244 * *$ & 0.00592 & $-0.0283 * *$ & -0.00221 & $-0.0171 *$ & $0.0526 * * *$ & -0.0135 & 0.000778 \\
\hline & $(0.0335)$ & $(0.0118)$ & $(0.00487)$ & $(0.0114)$ & $(0.00588)$ & $(0.0104)$ & $(0.0149)$ & $(0.0114)$ & $(0.00319)$ \\
\hline \multirow[t]{2}{*}{ tighten } & $0.00767 * *$ & $-0.00660 * * *$ & $0.00271 * * *$ & 0.00152 & $-0.00257 * * *$ & $0.00369 * * *$ & $0.00367 * *$ & $0.00477 * * *$ & 0.000483 \\
\hline & $(0.00351)$ & $(0.00123)$ & $(0.000510)$ & $(0.00119)$ & $(0.000616)$ & $(0.00109)$ & $(0.00157)$ & $(0.00120)$ & $(0.000334)$ \\
\hline \multirow[t]{2}{*}{ lnpincome } & $-0.213 * * *$ & $-0.154 * * *$ & $-0.00157 * * *$ & $-0.0340 * * *$ & $0.00248^{* * *}$ & $-0.0154 * * *$ & $-0.00361 * * *$ & $-0.00786^{* * *}$ & $0.00112 * * *$ \\
\hline & $(0.00304)$ & $(0.00107)$ & $(0.000442)$ & $(0.00103)$ & $(0.000534)$ & $(0.000941)$ & $(0.00136)$ & $(0.00104)$ & $(0.000290)$ \\
\hline \multirow[t]{2}{*}{$l t i$} & 0.0148 & $-0.0638 * * *$ & $-0.00729 * * *$ & $0.0412 * * *$ & $0.0134 * * *$ & $0.0425 * * *$ & $-0.0105^{*}$ & 0.00165 & $-0.00232 * *$ \\
\hline & $(0.0121)$ & $(0.00424)$ & $(0.00176)$ & $(0.00410)$ & $(0.00212)$ & $(0.00374)$ & $(0.00539)$ & $(0.00411)$ & $(0.00115)$ \\
\hline \multirow[t]{2}{*}{ child } & $0.0174 * * *$ & $-0.0251 * * *$ & $0.00515^{* * *}$ & $-0.0127 * * *$ & $-0.00321 * * *$ & $-0.00976^{* * *}$ & 0.000560 & $0.0619 * * *$ & $0.000639 * *$ \\
\hline & $(0.00309)$ & $(0.00109)$ & $(0.000450)$ & $(0.00105)$ & $(0.000544)$ & $(0.000958)$ & $(0.00138)$ & $(0.00105)$ & $(0.000295)$ \\
\hline \multirow[t]{2}{*}{ old } & $-0.0456^{* * *}$ & $-0.0178 * * *$ & $-0.00483 * * *$ & $-0.00308 * * *$ & $0.00175^{* * *}$ & -0.000527 & -0.000501 & $-0.0202 * * *$ & -0.000344 \\
\hline & $(0.00299)$ & $(0.00105)$ & $(0.000435)$ & $(0.00102)$ & $(0.000525)$ & $(0.000925)$ & $(0.00133)$ & $(0.00102)$ & $(0.000285)$ \\
\hline \multirow[t]{2}{*}{ lnasset } & 0.000406 & -0.000145 & $0.000785 * * *$ & $-0.00192 * * *$ & $0.000326^{* * *}$ & $0.000469^{* * *}$ & 0.000153 & $0.000600 * * *$ & $0.000134 * * *$ \\
\hline & $(0.000362)$ & $(0.000127)$ & $(0.0000527)$ & $(0.000123)$ & $(0.0000637)$ & $(0.000112)$ & $(0.000162)$ & $(0.000124)$ & $(0.0000346)$ \\
\hline \multirow[t]{2}{*}{ married } & $-0.276^{* * *}$ & $-0.0637 * * *$ & 0.00322 & -0.00397 & -0.000454 & $-0.0953 * * *$ & -0.00331 & $-0.0266 * * *$ & $-0.0857 * * *$ \\
\hline & $(0.0269)$ & $(0.00944)$ & $(0.00391)$ & $(0.00913)$ & $(0.00472)$ & $(0.00832)$ & $(0.0120)$ & $(0.00916)$ & $(0.00256)$ \\
\hline \multirow[t]{2}{*}{ age } & $0.0131 * * *$ & $0.00610 * * *$ & $-0.00105^{* * *}$ & $0.00328 * * *$ & -0.000201 & $-0.00449 * * *$ & $0.00254 * * *$ & $0.00696 * * *$ & -0.0000298 \\
\hline & $(0.000854)$ & $(0.000300)$ & $(0.000124)$ & $(0.000290)$ & $(0.000150)$ & $(0.000265)$ & $(0.000381)$ & $(0.000291)$ & $(0.0000814)$ \\
\hline \multirow[t]{2}{*}{ agesquare } & $-0.000131 * * *$ & $-0.0000521 * * *$ & $-0.00000496 * * *$ & $-0.0000271 * * *$ & 0.000000604 & $0.0000565 * * *$ & $-0.0000320 * * *$ & $-0.0000697 * * *$ & $-0.00000172 * *$ \\
\hline & $(0.00000808)$ & $(0.00000284)$ & $(0.00000118)$ & $(0.00000274)$ & $(0.00000142)$ & $(0.00000250)$ & $(0.00000361)$ & $(0.00000275)$ & $(0.000000770)$ \\
\hline \multirow[t]{2}{*}{ hukou } & $0.0344 * * *$ & $0.0254 * * *$ & $0.00311 * *$ & $-0.0239 * * *$ & $0.00448 * * *$ & 0.00325 & $0.0106^{* *}$ & $0.00800 * *$ & $0.00349 * * *$ \\
\hline & $(0.00950)$ & $(0.00334)$ & $(0.00138)$ & $(0.00323)$ & $(0.00167)$ & $(0.00294)$ & $(0.00424)$ & $(0.00324)$ & $(0.000906)$ \\
\hline \multirow[t]{2}{*}{ multihouse } & $0.0378 * * *$ & $-0.00377 * *$ & $-0.00207 * * *$ & $0.0222 * * *$ & $0.00716^{* * *}$ & -0.00138 & $0.00951 * * *$ & $0.00569 * * *$ & 0.000429 \\
\hline & $(0.00421)$ & $(0.00148)$ & $(0.000613)$ & $(0.00143)$ & $(0.000741)$ & $(0.00131)$ & $(0.00188)$ & $(0.00144)$ & $(0.000402)$ \\
\hline
\end{tabular}




\begin{tabular}{|c|c|c|c|c|c|c|c|c|c|}
\hline \multirow[t]{2}{*}{ lnareapp } & 0.00227 & $-0.0215 * * *$ & $0.00788 * * *$ & $0.00825 * * *$ & $0.00295 * * *$ & $-0.00356 * * *$ & $0.00873 * * *$ & -0.000807 & 0.000297 \\
\hline & $(0.00333)$ & $(0.00117)$ & $(0.000485)$ & $(0.00113)$ & $(0.000586)$ & $(0.00103)$ & (0.00149) & $(0.00114)$ & $(0.000318)$ \\
\hline \multirow[t]{2}{*}{ fanggaifang } & -0.00401 & $0.00354 * * *$ & $-0.00207 * * *$ & $-0.00622 * * *$ & $-0.00157 * * *$ & -0.000578 & $-0.00318 * *$ & $0.00579 * * *$ & 0.000268 \\
\hline & $(0.00282)$ & $(0.000993)$ & $(0.000411)$ & $(0.000960)$ & $(0.000497)$ & $(0.000875)$ & $(0.00126)$ & $(0.000963)$ & $(0.000269)$ \\
\hline \multirow[t]{2}{*}{ aveincgrowth } & $0.233 * * *$ & $0.149 * * *$ & $0.0601 * * *$ & -0.00673 & $0.0480 * * *$ & 0.0222 & 0.00333 & $-0.0558 * *$ & $0.0129 * *$ \\
\hline & $(0.0649)$ & $(0.0228)$ & $(0.00944)$ & $(0.0221)$ & $(0.0114)$ & $(0.0201)$ & $(0.0290)$ & $(0.0221)$ & $(0.00619)$ \\
\hline \multirow[t]{2}{*}{ Inhprice } & $0.0178 * * *$ & $0.0457 * * *$ & $0.00558 * * *$ & $-0.00442 * *$ & $-0.00708 * * *$ & $-0.00390 * *$ & 0.000810 & $-0.0197 * * *$ & 0.000788 \\
\hline & $(0.00516)$ & $(0.00181)$ & $(0.000751)$ & $(0.00175)$ & (0.000907) & $(0.00160)$ & $(0.00230)$ & $(0.00176)$ & $(0.000492)$ \\
\hline \multirow[t]{2}{*}{ pubsavrate } & -0.00847 & $-0.0127 * * *$ & -0.00106 & 0.000446 & $-0.00309 * *$ & $-0.00511^{* *}$ & $0.00701^{*}$ & $0.00733 * * *$ & $-0.00129 *$ \\
\hline & $(0.00811)$ & $(0.00285)$ & $(0.00118)$ & $(0.00276)$ & $(0.00143)$ & $(0.00251)$ & $(0.00362)$ & $(0.00277)$ & $(0.000773)$ \\
\hline \multirow[t]{2}{*}{ interest } & $-0.00821 * * *$ & -0.00110 & $-0.000858 *$ & -0.000221 & -0.000653 & $-0.00207 * *$ & $-0.00367 * * *$ & 0.000723 & -0.000360 \\
\hline & $(0.00303)$ & $(0.00106)$ & $(0.000441)$ & $(0.00103)$ & $(0.000533)$ & $(0.000939)$ & $(0.00135)$ & $(0.00103)$ & $(0.000289)$ \\
\hline education and occupation & $\mathrm{Y}$ & $\mathrm{Y}$ & $\mathrm{Y}$ & $\mathrm{Y}$ & $\mathrm{Y}$ & $\mathrm{Y}$ & $\mathrm{Y}$ & Y & Y \\
\hline region fixed effect & $\mathrm{Y}$ & $\mathrm{Y}$ & $\mathrm{Y}$ & $\mathrm{Y}$ & $\mathrm{Y}$ & $\mathrm{Y}$ & $\mathrm{Y}$ & $\mathrm{Y}$ & $\mathrm{Y}$ \\
\hline \multirow[t]{2}{*}{ cons } & $2.586^{* * * *}$ & $1.329 * * *$ & $0.0494 * * *$ & $0.356^{* * *}$ & $0.0766 * * *$ & $0.459 * * *$ & $0.0413 *$ & $0.180^{* * * *}$ & $0.0943 * * *$ \\
\hline & $(0.0540)$ & $(0.0190)$ & $(0.00785)$ & $(0.0183)$ & $(0.00948)$ & $(0.0167)$ & $(0.0241)$ & $(0.0184)$ & $(0.00515)$ \\
\hline $\mathrm{N}$ & 109920 & 109920 & 109920 & 109920 & 109920 & 109920 & 109920 & 109920 & 109920 \\
\hline R-sq & 0.101 & 0.338 & 0.184 & 0.035 & 0.015 & 0.055 & 0.023 & 0.100 & 0.031 \\
\hline
\end{tabular}

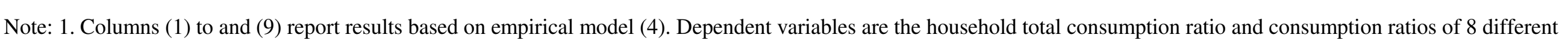
subcategories of consumption.

2. Robust standard errors are reported in parentheses: $* * *$ denotes $\mathrm{p}<0.01$, ** denotes $\mathrm{p}<0.05$, and $*$ denotes $\mathrm{p}<0.1$.

3. In denotes logarithm of the variable. 
Table 7 Minimum Down Payment Policy and the Impact of obtaining a New Mortgage on Consumption Ratio

\begin{tabular}{|c|c|c|c|c|c|c|c|c|c|}
\hline & $\begin{array}{l}\text { (1) } \\
\text { totalratio }\end{array}$ & $\begin{array}{l}\text { (2) } \\
\text { foodratio }\end{array}$ & $\begin{array}{l}\text { (3) } \\
\text { clothratio }\end{array}$ & $\begin{array}{l}\text { (4) } \\
\text { residentratio }\end{array}$ & $\begin{array}{l}\text { (5) } \\
\text { durableratio }\end{array}$ & $\begin{array}{l}\text { (6) } \\
\text { medicalratio }\end{array}$ & $\begin{array}{l}\text { (7) } \\
\text { transratio }\end{array}$ & $\begin{array}{l}\text { (8) } \\
\text { educateratio }\end{array}$ & $\begin{array}{l}(9) \\
\text { otherratio } \\
\end{array}$ \\
\hline mpayratio & $-0.261 * * *$ & $-0.0647 * * *$ & $-0.0372 * * *$ & -0.0173 & -0.0172 & $-0.0328 * * *$ & $-0.0483^{*}$ & $-0.0243^{*}$ & $-0.0192 * * *$ \\
\hline \multirow{3}{*}{$\begin{array}{l}\text { mpayratio } \times \text { newmortgage } \\
\times \text { tighten }\end{array}$} & $-0.427 * *$ & -0.0461 & 0.0165 & $-0.366^{* * *}$ & -0.0409 & -0.0177 & 0.0983 & $-0.0772 *$ & 0.00570 \\
\hline & & & & & & & & & \\
\hline & $(0.184)$ & $(0.0426)$ & $(0.0224)$ & $(0.0956)$ & $(0.0427)$ & $(0.0325)$ & $(0.0880)$ & $(0.0441)$ & $(0.0145)$ \\
\hline \multirow[t]{2}{*}{ mpayratio $\times$ newmortgage } & $0.423 * *$ & 0.0285 & 0.00968 & $0.245^{* * *}$ & 0.0230 & -0.00764 & 0.0967 & 0.0268 & 0.000925 \\
\hline & $(0.172)$ & $(0.0397)$ & $(0.0209)$ & $(0.0893)$ & $(0.0398)$ & $(0.0303)$ & $(0.0822)$ & $(0.0412)$ & $(0.0136)$ \\
\hline \multirow[t]{2}{*}{ mpayratio $\times$ tighten } & 0.0875 & 0.00638 & 0.00594 & $0.0829 * *$ & 0.0190 & 0.00517 & -0.0118 & -0.0278 & 0.00770 \\
\hline & $(0.0771)$ & $(0.0178)$ & $(0.00938)$ & $(0.0401)$ & $(0.0179)$ & $(0.0136)$ & $(0.0369)$ & $(0.0185)$ & $(0.00609)$ \\
\hline \multirow[t]{2}{*}{ tighten } & -0.00810 & $-0.00886^{* *}$ & 0.00308 & -0.0139 & -0.00614 & 0.00111 & 0.0133 & 0.00477 & -0.00145 \\
\hline & $(0.0179)$ & $(0.00415)$ & $(0.00218)$ & $(0.00932)$ & $(0.00416)$ & $(0.00316)$ & $(0.00858)$ & $(0.00430)$ & $(0.00142)$ \\
\hline newmortgage & $(0.0328)$ & $(0.00758)$ & $(0.00399)$ & $(0.0170)$ & $(0.00761)$ & $(0.00579)$ & $(0.0157)$ & $(0.00786)$ & $(0.00259)$ \\
\hline \multirow[t]{2}{*}{ Inpincome } & -0.0465 & $-0.112 * * *$ & $-0.0110^{*}$ & 0.0115 & $0.0379 * * *$ & $-0.0303 * * *$ & $0.0491 * *$ & 0.00623 & 0.00172 \\
\hline & $(0.0482)$ & $(0.0112)$ & $(0.00587)$ & $(0.0251)$ & $(0.0112)$ & $(0.00851)$ & $(0.0231)$ & $(0.0116)$ & $(0.00381)$ \\
\hline \multirow[t]{2}{*}{$l t i$} & $0.169 * * *$ & $-0.0281^{*}$ & -0.0110 & 0.0239 & $0.0782 * * *$ & 0.00168 & $0.0742 * *$ & $0.0282 *$ & 0.00192 \\
\hline & $(0.0651)$ & $(0.0151)$ & $(0.00792)$ & $(0.0338)$ & $(0.0151)$ & $(0.0115)$ & $(0.0311)$ & $(0.0156)$ & $(0.00514)$ \\
\hline \multirow[t]{2}{*}{ child } & 0.0153 & $-0.0243 * * *$ & 0.00212 & 0.00347 & 0.00304 & $-0.0111 * * *$ & 0.00541 & $0.0401 * * *$ & $-0.00348 * * *$ \\
\hline & $(0.0152)$ & $(0.00352)$ & $(0.00185)$ & $(0.00791)$ & $(0.00353)$ & $(0.00269)$ & $(0.00728)$ & $(0.00365)$ & $(0.00120)$ \\
\hline \multirow[t]{2}{*}{ old } & -0.0107 & $-0.0136 * * *$ & $-0.0121 * * *$ & 0.00668 & $0.0112 * *$ & -0.000920 & $0.0178^{*}$ & $-0.0179 * * *$ & -0.00180 \\
\hline & $(0.0206)$ & $(0.00477)$ & $(0.00251)$ & $(0.0107)$ & $(0.00479)$ & $(0.00364)$ & $(0.00987)$ & $(0.00495)$ & $(0.00163)$ \\
\hline \multirow[t]{2}{*}{ lnasset } & 0.00226 & -0.000873 & 0.000229 & -0.00173 & $0.00155^{* *}$ & -0.000379 & 0.00185 & $0.00141^{*}$ & 0.000210 \\
\hline & $(0.00315)$ & $(0.000728)$ & $(0.000383)$ & $(0.00164)$ & $(0.000731)$ & $(0.000556)$ & $(0.00151)$ & $(0.000755)$ & $(0.000249)$ \\
\hline \multirow[t]{2}{*}{ married } & -0.0198 & 0.00202 & -0.000826 & 0.00530 & 0.00827 & $-0.0404 * *$ & 0.0245 & 0.0276 & $-0.0463 * * *$ \\
\hline & $(0.109)$ & $(0.0251)$ & $(0.0132)$ & $(0.0564)$ & $(0.0252)$ & $(0.0192)$ & $(0.0519)$ & $(0.0260)$ & $(0.00858)$ \\
\hline
\end{tabular}




\begin{tabular}{|c|c|c|c|c|c|c|c|c|c|}
\hline & $(0.00547)$ & $(0.00127)$ & $(0.000666)$ & $(0.00285)$ & $(0.00127)$ & $(0.000967)$ & $(0.00262)$ & $(0.00131)$ & $(0.000433)$ \\
\hline \multirow[t]{2}{*}{ agesquare } & $-0.0000886^{*}$ & $-0.0000242 * *$ & $-0.0000221 * * *$ & -0.0000129 & -0.00000341 & $0.0000499 * * *$ & 0.00000910 & $-0.0000772 * * *$ & $-0.00000773 * *$ \\
\hline & $(0.0000471)$ & $(0.0000109)$ & $(0.00000573)$ & $(0.0000245)$ & $(0.0000109)$ & $(0.00000832)$ & $(0.0000225)$ & $(0.0000113)$ & $(0.00000372)$ \\
\hline \multirow[t]{2}{*}{ hukou } & 0.0135 & $0.0180 * *$ & 0.00467 & -0.0242 & -0.00910 & 0.00657 & 0.0189 & -0.00223 & 0.000828 \\
\hline & $(0.0368)$ & $(0.00851)$ & $(0.00448)$ & $(0.0191)$ & $(0.00854)$ & $(0.00650)$ & $(0.0176)$ & $(0.00883)$ & $(0.00291)$ \\
\hline \multirow[t]{2}{*}{ multihouse } & $0.0323 * *$ & $-0.00487 *$ & $-0.00362 * *$ & $0.0318 * * *$ & $0.0122 * * *$ & $-0.00420^{*}$ & -0.00286 & 0.00436 & -0.000509 \\
\hline & $(0.0127)$ & $(0.00293)$ & $(0.00154)$ & $(0.00659)$ & $(0.00294)$ & $(0.00224)$ & $(0.00607)$ & $(0.00304)$ & $(0.00100)$ \\
\hline \multirow[t]{2}{*}{ Inareapp } & 0.0152 & $-0.0133 * * *$ & $0.00921 * * *$ & 0.00435 & -0.00568 & 0.000980 & $0.0138 *$ & 0.00372 & $0.00216^{*}$ \\
\hline & $(0.0156)$ & $(0.00361)$ & $(0.00190)$ & $(0.00811)$ & $(0.00362)$ & $(0.00275)$ & $(0.00746)$ & $(0.00374)$ & $(0.00123)$ \\
\hline \multirow[t]{2}{*}{ fanggaifang } & $0.0198 *$ & 0.00200 & $0.00349 * *$ & 0.00622 & 0.00311 & 0.000988 & -0.00317 & $0.00693 * *$ & 0.000207 \\
\hline & $(0.0119)$ & $(0.00276)$ & $(0.00145)$ & $(0.00620)$ & $(0.00277)$ & $(0.00211)$ & $(0.00571)$ & $(0.00286)$ & $(0.000942)$ \\
\hline \multirow[t]{2}{*}{ aveincgrowth } & 0.300 & $0.0942 *$ & 0.0273 & 0.0782 & $0.172 * * *$ & -0.0412 & -0.0672 & 0.0245 & 0.0123 \\
\hline & $(0.227)$ & $(0.0526)$ & $(0.0277)$ & $(0.118)$ & $(0.0527)$ & $(0.0401)$ & (0.109) & $(0.0545)$ & $(0.0180)$ \\
\hline \multirow[t]{2}{*}{ lnhprice } & -0.00688 & $0.0339 * * *$ & $0.00835 * * *$ & $-0.0300 * * *$ & $-0.0134 * * *$ & -0.00257 & 0.00535 & $-0.00898 * *$ & 0.000409 \\
\hline & $(0.0175)$ & $(0.00406)$ & $(0.00214)$ & $(0.00912)$ & $(0.00407)$ & $(0.00310)$ & $(0.00840)$ & $(0.00421)$ & $(0.00139)$ \\
\hline \multirow[t]{2}{*}{ pubsavrate } & $-0.0870 * *$ & -0.00482 & $-0.0116^{* * *}$ & $-0.0326^{*}$ & -0.00437 & $-0.0135^{* *}$ & 0.00196 & $-0.0223^{* * *}$ & 0.000214 \\
\hline & $(0.0348)$ & $(0.00804)$ & $(0.00423)$ & $(0.0181)$ & $(0.00807)$ & $(0.00614)$ & $(0.0166)$ & $(0.00834)$ & $(0.00275)$ \\
\hline \multirow[t]{2}{*}{ lambdamort } & 0.162 & -0.0345 & -0.00345 & 0.0520 & $0.0818 * * *$ & $-0.0348 *$ & 0.0719 & 0.0294 & -0.000250 \\
\hline & $(0.103)$ & $(0.0238)$ & $(0.0125)$ & $(0.0535)$ & $(0.0239)$ & $(0.0182)$ & $(0.0493)$ & $(0.0247)$ & $(0.00814)$ \\
\hline education and & $\mathrm{Y}$ & $\mathrm{Y}$ & $\mathrm{Y}$ & $\mathrm{Y}$ & $\mathrm{Y}$ & $\mathrm{Y}$ & $\mathrm{Y}$ & $\mathrm{Y}$ & $\mathrm{Y}$ \\
\hline \multicolumn{10}{|l|}{ occupation } \\
\hline region fixed effect & $\mathrm{Y}$ & $\mathrm{Y}$ & $\mathrm{Y}$ & $\mathrm{Y}$ & $\mathrm{Y}$ & $\mathrm{Y}$ & $\mathrm{Y}$ & $\mathrm{Y}$ & $\mathrm{Y}$ \\
\hline \multirow[t]{2}{*}{ _cons } & 0.912 & $1.080 * * *$ & 0.0589 & 0.154 & $-0.280^{*}$ & $0.554 * * *$ & $-0.553^{*}$ & -0.150 & 0.0480 \\
\hline & $(0.650)$ & $(0.150)$ & $(0.0791)$ & $(0.338)$ & $(0.151)$ & $(0.115)$ & $(0.311)$ & $(0.156)$ & $(0.0514)$ \\
\hline $\mathrm{N}$ & 6741 & 6741 & 6741 & 6741 & 6741 & 6741 & 6741 & 6741 & 6741 \\
\hline R-sq & 0.059 & 0.303 & 0.168 & 0.056 & 0.032 & 0.057 & 0.032 & 0.095 & 0.035 \\
\hline
\end{tabular}

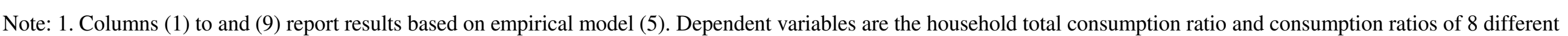
subcategories of consumption.

2. Robust standard errors are reported in parentheses: $* * *$ denotes $\mathrm{p}<0.01$, ** denotes $\mathrm{p}<0.05$, and $*$ denotes $\mathrm{p}<0.1$. 
3. In denotes logarithm of the variable.

4. lambdamort denotes the inverse Mills ratio calculated by the Heckman process to control for the selection bias of mortgage acquisition, and is estimated in Column (1) of Table 4. 
Table 8 Impact of Having a Mortgage on Household Consumption Ratio (Robustness Check Using an IV)

\begin{tabular}{|c|c|c|c|c|c|c|c|c|c|c|}
\hline & $\begin{array}{l}\text { (1) } \\
\text { Dmortgage }\end{array}$ & $\begin{array}{l}\text { (2) } \\
\text { totalratio }\end{array}$ & $\begin{array}{l}\text { (3) } \\
\text { foodratio }\end{array}$ & $\begin{array}{l}\text { (4) } \\
\text { clothratio }\end{array}$ & $\begin{array}{l}\text { (5) } \\
\text { residentratio }\end{array}$ & $\begin{array}{l}\text { (6) } \\
\text { durableratio }\end{array}$ & $\begin{array}{l}\text { (7) } \\
\text { medicalratio }\end{array}$ & $\begin{array}{l}\text { (8) } \\
\text { transratio }\end{array}$ & (9) & (9) \\
\hline literacy & $\begin{array}{l}0.0606 * * \\
(0.0293)\end{array}$ & & & & & & & & & \\
\hline Dmortgage & & $\begin{array}{l}0.303 * * * \\
(0.0317)\end{array}$ & $\begin{array}{l}0.160 * * * \\
(0.0115)\end{array}$ & $\begin{array}{l}-0.0626 * * * \\
(0.00462)\end{array}$ & $\begin{array}{l}0.0760 * * * \\
(0.0106)\end{array}$ & $\begin{array}{l}-0.00251 \\
(0.00546)\end{array}$ & $\begin{array}{l}0.00625 \\
(0.00961)\end{array}$ & $\begin{array}{l}0.121 * * * \\
(0.0141)\end{array}$ & $\begin{array}{l}0.0000719 \\
(0.0106)\end{array}$ & $\begin{array}{l}0.00569 * \\
(0.00296)\end{array}$ \\
\hline lnpincome & $\begin{array}{l}0.491 * * * \\
(0.0139)\end{array}$ & $\begin{array}{l}-0.206 * * * \\
(0.00277)\end{array}$ & $\begin{array}{l}-0.151 * * * \\
(0.00100)\end{array}$ & $\begin{array}{l}-0.00333 * * * \\
(0.000404)\end{array}$ & $\begin{array}{l}-0.0314 * * * \\
(0.000924)\end{array}$ & $\begin{array}{l}0.00131 * * * \\
(0.000477)\end{array}$ & $\begin{array}{l}-0.0150 * * * \\
(0.000841)\end{array}$ & $\begin{array}{l}0.000468 \\
(0.00123)\end{array}$ & $\begin{array}{l}-0.00834 * * * \\
(0.000925)\end{array}$ & $\begin{array}{l}0.00124 * * * \\
(0.000259)\end{array}$ \\
\hline lti & $\begin{array}{l}0.647 * * * \\
(0.0418)\end{array}$ & $\begin{array}{l}0.0219 * \\
(0.0123)\end{array}$ & $\begin{array}{l}-0.0608 * * * \\
(0.00446)\end{array}$ & $\begin{array}{l}-0.00877 * * * \\
(0.00180)\end{array}$ & $\begin{array}{l}0.0450 * * * \\
(0.00411)\end{array}$ & $\begin{array}{l}0.0113 * * * \\
(0.00212)\end{array}$ & $\begin{array}{l}0.0435 * * * \\
(0.00374)\end{array}$ & $\begin{array}{l}-0.00717 \\
(0.00549)\end{array}$ & $\begin{array}{l}0.000958 \\
(0.00412)\end{array}$ & $\begin{array}{l}-0.00206^{*} \\
(0.00115)\end{array}$ \\
\hline child & $\begin{array}{l}0.0514 * * * \\
(0.0182)\end{array}$ & $\begin{array}{l}0.0178 * * * \\
(0.00315)\end{array}$ & $\begin{array}{l}-0.0250 * * * \\
(0.00114)\end{array}$ & $\begin{array}{l}0.00500^{* * *} \\
(0.000460)\end{array}$ & $\begin{array}{l}-0.0126 * * * \\
(0.00105)\end{array}$ & $\begin{array}{l}-0.00331 * * * \\
(0.000543)\end{array}$ & $\begin{array}{l}-0.00977 * * * \\
(0.000957)\end{array}$ & $\begin{array}{l}0.00103 \\
(0.00140)\end{array}$ & $\begin{array}{l}0.0618 * * * \\
(0.00105)\end{array}$ & $\begin{array}{l}0.000627 * * \\
(0.000295)\end{array}$ \\
\hline old & $\begin{array}{l}0.174 * * * \\
(0.0181)\end{array}$ & $\begin{array}{l}-0.0440 * * * \\
(0.00303)\end{array}$ & $\begin{array}{l}-0.0172 * * * \\
(0.00110)\end{array}$ & $\begin{array}{l}-0.00522 * * * \\
(0.000442)\end{array}$ & $\begin{array}{l}-0.00244 * * \\
(0.00101)\end{array}$ & $\begin{array}{l}0.00144 * * * \\
(0.000522)\end{array}$ & $\begin{array}{l}-0.000463 \\
(0.000920)\end{array}$ & $\begin{array}{l}0.000445 \\
(0.00135)\end{array}$ & $\begin{array}{l}-0.0203 * * * \\
(0.00101)\end{array}$ & $\begin{array}{l}-0.000314 \\
(0.000284)\end{array}$ \\
\hline lnasset & $\begin{array}{l}0.0363 * * * \\
(0.00226)\end{array}$ & $\begin{array}{c}-0.0000263 \\
(0.000389)\end{array}$ & $\begin{array}{l}-0.000381 * * * \\
(0.000141)\end{array}$ & $\begin{array}{l}0.000877 * * * \\
(0.0000567)\end{array}$ & $\begin{array}{l}-0.00199 * * * \\
(0.000130)\end{array}$ & $\begin{array}{l}0.000288 * * * \\
(0.0000670)\end{array}$ & $\begin{array}{l}0.000479 * * * \\
(0.000118)\end{array}$ & $\begin{array}{l}-0.00000761 \\
(0.000173)\end{array}$ & $\begin{array}{l}0.000581 * * * \\
(0.000130)\end{array}$ & $\begin{array}{l}0.000129 * * * \\
(0.0000364)\end{array}$ \\
\hline married & $\begin{array}{l}0.143 \\
(0.153)\end{array}$ & $\begin{array}{l}-0.276^{* * *} \\
(0.0274)\end{array}$ & $\begin{array}{l}-0.0635 * * * \\
(0.00992)\end{array}$ & $\begin{array}{l}0.00245 \\
(0.00400)\end{array}$ & $\begin{array}{l}-0.00375 \\
(0.00915)\end{array}$ & $\begin{array}{l}-0.00138 \\
(0.00472)\end{array}$ & $\begin{array}{l}-0.0948 * * * \\
(0.00832)\end{array}$ & $\begin{array}{l}-0.00165 \\
(0.0122)\end{array}$ & $\begin{array}{l}-0.0277 * * * \\
(0.00916)\end{array}$ & $\begin{array}{l}-0.0858 * * * \\
(0.00257)\end{array}$ \\
\hline age & $\begin{array}{l}-0.0391 * * * \\
(0.00498)\end{array}$ & $\begin{array}{l}0.0119 * * * \\
(0.000851)\end{array}$ & $\begin{array}{l}0.00550 * * * \\
(0.000308)\end{array}$ & $\begin{array}{l}-0.000816^{* * *} \\
(0.000124)\end{array}$ & $\begin{array}{l}0.00286 * * * \\
(0.000284)\end{array}$ & $\begin{array}{l}-0.0000575 \\
(0.000147)\end{array}$ & $\begin{array}{l}-0.00455 * * * \\
(0.000258)\end{array}$ & $\begin{array}{l}0.00205^{* * *} \\
(0.000379)\end{array}$ & $\begin{array}{l}0.00697 * * * \\
(0.000284)\end{array}$ & $\begin{array}{l}-0.0000675 \\
(0.0000796)\end{array}$ \\
\hline agesquare & $\begin{array}{l}0.000194 * * * \\
(0.0000520)\end{array}$ & $\begin{array}{l}-0.000123^{* * *} \\
(0.00000816)\end{array}$ & $\begin{array}{l}-0.0000485 * * * \\
(0.00000295)\end{array}$ & $\begin{array}{l}-0.00000640^{* * *} \\
(0.00000119)\end{array}$ & $\begin{array}{l}-0.0000246 * * * \\
(0.00000272)\end{array}$ & $\begin{array}{l}-0.000000362 \\
(0.00000141)\end{array}$ & $\begin{array}{l}0.0000570 * * * \\
(0.00000248)\end{array}$ & $\begin{array}{l}-0.0000292 * * * \\
(0.00000363)\end{array}$ & $\begin{array}{l}-0.0000699 * * * \\
(0.00000273)\end{array}$ & $\begin{array}{l}-0.00000149 * \\
(0.000000764)\end{array}$ \\
\hline hukou & $\begin{array}{l}-0.192 * * * \\
(0.0467)\end{array}$ & $\begin{array}{l}0.0277 * * * \\
(0.00965)\end{array}$ & $\begin{array}{l}0.0222 * * * \\
(0.00349)\end{array}$ & $\begin{array}{l}0.00430 * * * \\
(0.00141)\end{array}$ & $\begin{array}{l}-0.0261 * * * \\
(0.00322)\end{array}$ & $\begin{array}{l}0.00504 * * * \\
(0.00166)\end{array}$ & $\begin{array}{l}0.00306 \\
(0.00293)\end{array}$ & $\begin{array}{l}0.00817^{*} \\
(0.00429)\end{array}$ & $\begin{array}{l}0.00778 * * \\
(0.00323)\end{array}$ & $\begin{array}{l}0.00328 * * * \\
(0.000903)\end{array}$ \\
\hline multihouse & $\begin{array}{l}0.358 * * * \\
(0.0192)\end{array}$ & $\begin{array}{l}0.0208 * * * \\
(0.00477)\end{array}$ & $\begin{array}{l}-0.0128 * * * \\
(0.00172)\end{array}$ & $\begin{array}{l}0.00149 * * \\
(0.000695)\end{array}$ & $\begin{array}{l}0.0180 * * * \\
(0.00159)\end{array}$ & $\begin{array}{l}0.00723^{* * *} \\
(0.000821)\end{array}$ & $\begin{array}{l}-0.00173 \\
(0.00145)\end{array}$ & $\begin{array}{l}0.00282 \\
(0.00212)\end{array}$ & $\begin{array}{l}0.00565^{* * *} \\
(0.00159)\end{array}$ & $\begin{array}{l}0.000130 \\
(0.000446)\end{array}$ \\
\hline lnareapp & $0.166^{* * *}$ & -0.00217 & $-0.0240 * * *$ & $0.00888 * * *$ & $0.00718 * * *$ & $0.00306^{* * *}$ & $-0.00373 * * *$ & $0.00683 * * *$ & -0.000663 & 0.000229 \\
\hline
\end{tabular}




\begin{tabular}{|c|c|c|c|c|c|c|c|c|c|c|}
\hline & $(0.0208)$ & $(0.00344)$ & $(0.00125)$ & $(0.000502)$ & $(0.00115)$ & $(0.000593)$ & $(0.00105)$ & $(0.00153)$ & $(0.00115)$ & $(0.000322)$ \\
\hline \multirow[t]{2}{*}{ fanggaifang } & $-0.503 * * *$ & $0.0150 * * *$ & $0.0137 * * *$ & $-0.00593 * * *$ & -0.00153 & $-0.00158 * *$ & -0.000163 & $0.00406^{* *}$ & $0.00584 * * *$ & $0.000634^{*}$ \\
\hline & $(0.0154)$ & $(0.00363)$ & $(0.00131)$ & $(0.000529)$ & $(0.00121)$ & $(0.000625)$ & $(0.00110)$ & $(0.00161)$ & $(0.00121)$ & $(0.000340)$ \\
\hline \multirow[t]{2}{*}{ aveincgrowth } & 0.237 & $0.143^{* *}$ & $0.137 * * *$ & $0.0563^{* * *}$ & -0.0263 & $0.0313^{* * *}$ & $0.0481^{* *}$ & -0.0112 & $-0.101 * * *$ & 0.00920 \\
\hline & $(0.386)$ & $(0.0685)$ & $(0.0248)$ & (0.00999) & $(0.0229)$ & $(0.0118)$ & $(0.0208)$ & $(0.0305)$ & $(0.0229)$ & $(0.00641)$ \\
\hline \multirow[t]{2}{*}{ Inhprice } & -0.0713 & $-0.0861 * * *$ & $-0.0190 * * *$ & $0.00732 * * *$ & $-0.0265^{* * *}$ & $-0.0150 * * *$ & $-0.0114 * * *$ & $0.0111^{*}$ & $-0.0268 * * *$ & $-0.00587 * * *$ \\
\hline & $(0.0797)$ & $(0.0138)$ & $(0.00500)$ & $(0.00202)$ & $(0.00461)$ & $(0.00238)$ & $(0.00420)$ & $(0.00615)$ & $(0.00462)$ & $(0.00129)$ \\
\hline \multirow[t]{2}{*}{ pubsavrate } & $0.150 * * *$ & -0.00567 & $-0.0115^{* * *}$ & -0.000130 & 0.00185 & -0.00200 & $-0.00432 *$ & 0.00389 & $0.00779 * * *$ & -0.00122 \\
\hline & $(0.0481)$ & $(0.00847)$ & $(0.00306)$ & $(0.00124)$ & $(0.00283)$ & $(0.00146)$ & $(0.00257)$ & $(0.00377)$ & $(0.00283)$ & $(0.000793)$ \\
\hline $\begin{array}{l}\text { education and } \\
\text { occupation }\end{array}$ & $\mathrm{Y}$ & $\mathrm{Y}$ & $\mathrm{Y}$ & $\mathrm{Y}$ & $\mathrm{Y}$ & $\mathrm{Y}$ & $\mathrm{Y}$ & $\mathrm{Y}$ & $\mathrm{Y}$ & $\mathrm{Y}$ \\
\hline $\begin{array}{l}\text { year fixed } \\
\text { effect }\end{array}$ & $\mathrm{Y}$ & $\mathrm{Y}$ & $\mathrm{Y}$ & $\mathrm{Y}$ & $\mathrm{Y}$ & $\mathrm{Y}$ & $\mathrm{Y}$ & $\mathrm{Y}$ & $\mathrm{Y}$ & $\mathrm{Y}$ \\
\hline $\begin{array}{l}\text { region fixed } \\
\text { effect }\end{array}$ & $\mathrm{Y}$ & $\mathrm{Y}$ & $\mathrm{Y}$ & $\mathrm{Y}$ & $\mathrm{Y}$ & $\mathrm{Y}$ & $\mathrm{Y}$ & $\mathrm{Y}$ & $\mathrm{Y}$ & $\mathrm{Y}$ \\
\hline _cons & $\begin{array}{l}-5.310^{* * *} \\
(0.727)\end{array}$ & $\begin{array}{l}3.420 * * * \\
(0.127)\end{array}$ & $\begin{array}{l}1.864 * * * \\
(0.0458)\end{array}$ & $\begin{array}{l}0.0372 * * \\
(0.0185)\end{array}$ & $\begin{array}{l}0.539 * * * \\
(0.0423)\end{array}$ & $\begin{array}{l}0.150 * * * \\
(0.0218)\end{array}$ & $\begin{array}{l}0.504 * * * \\
(0.0385)\end{array}$ & $\begin{array}{l}-0.0826 \\
(0.0564)\end{array}$ & $\begin{array}{l}0.259 * * * \\
(0.0423)\end{array}$ & $\begin{array}{l}0.149 * * * \\
(0.0119)\end{array}$ \\
\hline $\mathrm{N}$ & 109920 & 109920 & 109920 & 109920 & 109920 & 109920 & 109920 & 109920 & 109920 & 109920 \\
\hline R-sq & & 0.065 & 0.269 & 0.147 & 0.031 & 0.015 & 0.032 & 0.100 & 0.028 & 0.041 \\
\hline
\end{tabular}

Note: 1. Column (1) reports the first-stage results of instrument regression where the dependent variable is whether or not the household has a mortgage. We use financial literacy as an instrument that takes the value of 1 if the household head has worked in the financial sector or the real estate industry, and zero otherwise. Columns (2) to and (10) report results of consumption regressions using 2SLS with the instrumental variable regression. Dependent variables in columns (2)-(10) are the household total consumption ratio and consumption ratios of 8 different subcategories of consumption.

2. Robust standard errors are reported in parentheses: $* * *$ denotes $\mathrm{p}<0.01$, $* *$ denotes $\mathrm{p}<0.05$, and $*$ denotes $\mathrm{p}<0.1$.

3. In denotes logarithm of the variable.

4. Dmortgage denotes the probability of having a mortgage estimated from the first-stage results of instrument regression. 
Table 9 Impact of Mortgage Payment Ratio on Household Consumption Ratio (Robustness Check Using PSM I)

\begin{tabular}{|c|c|c|c|c|c|c|c|c|c|}
\hline & $\begin{array}{l}(1) \\
\text { totalratio }\end{array}$ & $\begin{array}{l}(2) \\
\text { foodratio }\end{array}$ & $\begin{array}{l}(3) \\
\text { clothratio }\end{array}$ & $\begin{array}{l}(4) \\
\text { residentratio }\end{array}$ & $\begin{array}{l}\text { (5) } \\
\text { durableratio }\end{array}$ & $\begin{array}{l}(6) \\
\text { medicalratio }\end{array}$ & $\begin{array}{l}(7) \\
\text { transratio }\end{array}$ & $\begin{array}{l}\text { (8) } \\
\text { educateratio }\end{array}$ & $\begin{array}{l}(9) \\
\text { otherratio }\end{array}$ \\
\hline \multirow[t]{2}{*}{ Dmortgage } & 0.0126 & $-0.0171 * * *$ & $-0.00413 * * *$ & $0.0291 * * *$ & $0.0123 * * *$ & $0.00318 *$ & -0.00559 & $-0.00461 *$ & -0.000487 \\
\hline & $(0.00934)$ & $(0.00230)$ & $(0.00120)$ & $(0.00423)$ & $(0.00196)$ & $(0.00172)$ & $(0.00519)$ & $(0.00243)$ & $(0.000760)$ \\
\hline \multirow[t]{2}{*}{ Dmortgage $\times$ mpayratio } & $-0.257 * * *$ & $-0.0691 * * *$ & $-0.0352 * * *$ & 0.00278 & $-0.0177 * *$ & $-0.0330 * * *$ & $-0.0522 * *$ & $-0.0377 * * *$ & $-0.0152 * * *$ \\
\hline & $(0.0369)$ & $(0.00911)$ & $(0.00475)$ & $(0.0167)$ & $(0.00777)$ & $(0.00682)$ & $(0.0205)$ & $(0.00961)$ & $(0.00300)$ \\
\hline \multirow[t]{2}{*}{ lnpincome } & $-0.143^{* * *}$ & $-0.110 * * *$ & $-0.0120 * * *$ & $-0.0151 * * *$ & 0.000633 & $-0.0138 * * *$ & $0.0125 * * *$ & $-0.00772 * * *$ & $0.00162 * * *$ \\
\hline & $(0.00695)$ & $(0.00171)$ & $(0.000894)$ & $(0.00315)$ & $(0.00146)$ & $(0.00128)$ & $(0.00386)$ & $(0.00181)$ & $(0.000565)$ \\
\hline \multirow[t]{2}{*}{$l t i$} & $0.159 * * *$ & 0.000138 & $-0.00658 * * *$ & $0.0992 * * *$ & $0.0144 * * *$ & $0.0355 * * *$ & $0.0152 *$ & 0.00268 & -0.00122 \\
\hline & $(0.0161)$ & $(0.00397)$ & $(0.00207)$ & $(0.00730)$ & $(0.00339)$ & $(0.00297)$ & $(0.00894)$ & $(0.00419)$ & $(0.00131)$ \\
\hline \multirow[t]{2}{*}{ child } & 0.00618 & $-0.0214 * * *$ & $0.00280 * *$ & -0.00610 & -0.00274 & $-0.00757 * * *$ & 0.000763 & $0.0421 * * *$ & $-0.00166 * *$ \\
\hline & $(0.00929)$ & $(0.00229)$ & $(0.00120)$ & $(0.00421)$ & $(0.00195)$ & $(0.00171)$ & $(0.00516)$ & $(0.00242)$ & $(0.000756)$ \\
\hline \multirow[t]{2}{*}{ old } & $-0.0308 * * *$ & $-0.00787 * * *$ & $-0.0139 * * *$ & 0.00251 & -0.000796 & $0.00439 * *$ & 0.00772 & $-0.0212 * * *$ & $-0.00163 * *$ \\
\hline & $(0.00963)$ & $(0.00237)$ & $(0.00124)$ & $(0.00436)$ & $(0.00202)$ & $(0.00178)$ & $(0.00534)$ & $(0.00251)$ & $(0.000783)$ \\
\hline \multirow[t]{2}{*}{ lnasset } & 0.000481 & $0.000724 * *$ & $0.000489 * * *$ & $-0.00239 * * *$ & -0.000182 & $0.000593 * * *$ & 0.000254 & $0.000782 * *$ & $0.000213^{* *}$ \\
\hline & $(0.00124)$ & $(0.000306)$ & $(0.000160)$ & $(0.000562)$ & $(0.000261)$ & $(0.000229)$ & $(0.000689)$ & $(0.000323)$ & $(0.000101)$ \\
\hline \multirow[t]{2}{*}{ married } & -0.0179 & 0.00239 & -0.00175 & 0.0114 & 0.00808 & -0.0197 & 0.00108 & 0.0156 & $-0.0350 * * *$ \\
\hline & $(0.0915)$ & $(0.0226)$ & $(0.0118)$ & $(0.0414)$ & $(0.0192)$ & $(0.0169)$ & $(0.0508)$ & $(0.0238)$ & $(0.00744)$ \\
\hline \multirow[t]{2}{*}{ age } & $0.00900 * * *$ & $0.00227 * * *$ & $0.00139 * * *$ & $0.00232 *$ & 0.000856 & $-0.00338 * * *$ & $-0.00275^{*}$ & $0.00792 * * *$ & 0.000361 \\
\hline & $(0.00270)$ & $(0.000667)$ & $(0.000348)$ & $(0.00122)$ & $(0.000569)$ & $(0.000499)$ & $(0.00150)$ & $(0.000704)$ & $(0.000220)$ \\
\hline \multirow[t]{2}{*}{ agesquare } & $-0.000118 * * *$ & $-0.0000221 * * *$ & $-0.0000261 * * *$ & -0.0000202 & -0.00000909 & $0.0000408 * * *$ & 0.00000941 & $-0.0000835 * * *$ & $-0.00000714 * * *$ \\
\hline & $(0.0000293)$ & $(0.00000724)$ & $(0.00000378)$ & $(0.0000133)$ & $(0.00000617)$ & $(0.00000541)$ & $(0.0000163)$ & $(0.00000764)$ & $(0.00000239)$ \\
\hline \multirow[t]{2}{*}{ hukou } & $0.0570 * * *$ & $0.0156^{* * *}$ & $0.00761 * * *$ & -0.00358 & $0.00966 * *$ & 0.00288 & $0.0236^{* *}$ & 0.000944 & 0.000331 \\
\hline & $(0.0211)$ & $(0.00520)$ & $(0.00271)$ & $(0.00955)$ & $(0.00444)$ & $(0.00389)$ & $(0.0117)$ & $(0.00549)$ & $(0.00172)$ \\
\hline \multirow[t]{2}{*}{ multihouse } & $0.0386^{* * *}$ & $-0.00401^{*}$ & -0.000556 & $0.0253 * * *$ & $0.00851 * * *$ & $-0.00325^{* *}$ & 0.00673 & $0.00577 * *$ & 0.0000802 \\
\hline & $(0.00867)$ & $(0.00214)$ & $(0.00112)$ & $(0.00393)$ & $(0.00182)$ & $(0.00160)$ & $(0.00481)$ & $(0.00226)$ & $(0.000705)$ \\
\hline \multirow[t]{2}{*}{ lnareapp } & 0.0152 & $-0.0162 * * *$ & $0.00875^{* * *}$ & 0.00586 & -0.00246 & -0.00157 & $0.0151 * *$ & 0.00369 & $0.00204 * *$ \\
\hline & $(0.0108)$ & $(0.00266)$ & (0.00139) & $(0.00488)$ & $(0.00227)$ & $(0.00199)$ & $(0.00598)$ & $(0.00281)$ & $(0.000877)$ \\
\hline
\end{tabular}




\begin{tabular}{|c|c|c|c|c|c|c|c|c|c|}
\hline \multirow[t]{2}{*}{ fanggaifang } & 0.00735 & -0.0000119 & -0.000592 & 0.00156 & 0.00112 & -0.000989 & -0.000189 & $0.00664 * * *$ & -0.000198 \\
\hline & $(0.00806)$ & (0.00199) & $(0.00104)$ & $(0.00365)$ & $(0.00170)$ & $(0.00149)$ & $(0.00447)$ & $(0.00210)$ & $(0.000656)$ \\
\hline \multirow[t]{2}{*}{ aveincgrowth } & 0.286 & $0.167 * * *$ & 0.0418 & -0.0528 & $0.0815^{*}$ & $0.0671 *$ & 0.0234 & -0.0427 & 0.0000596 \\
\hline & $(0.198)$ & $(0.0488)$ & $(0.0255)$ & $(0.0897)$ & $(0.0416)$ & $(0.0365)$ & $(0.110)$ & $(0.0515)$ & $(0.0161)$ \\
\hline \multirow[t]{2}{*}{ Inhprice } & $-0.105^{* *}$ & $-0.0313 * * *$ & $0.00971 *$ & $-0.0369 * *$ & $-0.0257 * * *$ & $-0.0185^{* *}$ & 0.0238 & -0.0156 & $-0.0105^{* * *}$ \\
\hline & $(0.0415)$ & $(0.0102)$ & $(0.00535)$ & $(0.0188)$ & $(0.00873)$ & $(0.00766)$ & $(0.0231)$ & $(0.0108)$ & $(0.00338)$ \\
\hline \multirow[t]{2}{*}{ pubsavrate } & -0.0249 & 0.00357 & $-0.00943 * * *$ & -0.00627 & 0.00135 & -0.00283 & -0.00205 & -0.00732 & -0.00197 \\
\hline & $(0.0245)$ & $(0.00606)$ & $(0.00316)$ & $(0.0111)$ & $(0.00516)$ & $(0.00453)$ & $(0.0136)$ & $(0.00639)$ & $(0.00200)$ \\
\hline education and occupation & $\mathrm{Y}$ & $\mathrm{Y}$ & $\mathrm{Y}$ & $\mathrm{Y}$ & $\mathrm{Y}$ & $\mathrm{Y}$ & $\mathrm{Y}$ & $\mathrm{Y}$ & $\mathrm{Y}$ \\
\hline year fixed effect & $\mathrm{Y}$ & $\mathrm{Y}$ & $\mathrm{Y}$ & $\mathrm{Y}$ & $\mathrm{Y}$ & $\mathrm{Y}$ & $\mathrm{Y}$ & $\mathrm{Y}$ & $\mathrm{Y}$ \\
\hline region fixed effect & $\mathrm{Y}$ & $\mathrm{Y}$ & $\mathrm{Y}$ & $\mathrm{Y}$ & $\mathrm{Y}$ & $\mathrm{Y}$ & $\mathrm{Y}$ & $\mathrm{Y}$ & $\mathrm{Y}$ \\
\hline \multirow[t]{2}{*}{ _cons } & $2.780 * * *$ & $1.572 * * *$ & 0.0433 & $0.483 * * *$ & $0.243 * * *$ & $0.433 * * *$ & -0.210 & 0.0865 & $0.129 * * *$ \\
\hline & $(0.380)$ & $(0.0938)$ & $(0.0490)$ & $(0.172)$ & $(0.0800)$ & $(0.0702)$ & $(0.211)$ & $(0.0990)$ & $(0.0309)$ \\
\hline $\mathrm{N}$ & 13770 & 13770 & 13770 & 13770 & 13770 & 13770 & 13770 & 13770 & 13770 \\
\hline R-sq & 0.067 & 0.344 & 0.181 & 0.037 & 0.022 & 0.064 & 0.025 & 0.089 & 0.037 \\
\hline
\end{tabular}

Note: 1. Adopting PSM, we first estimate the probability of having a mortgage payment for each household. We then match each household with a mortgage to a household without a mortgage, using their probabilities of having a mortgage. Then, we include the interaction term of estimated probability of having a mortgage and mortgage payment ratio and run the regression based on empirical model (2). Columns (1) to and (9) report results after the PSM process. Dependent variables are the household total consumption ratio and consumption ratios of 8 different subcategories of consumption.

2. Robust standard errors are reported in parentheses: *** denotes $\mathrm{p}<0.01, * *$ denotes $\mathrm{p}<0.05$, and $*$ denotes $\mathrm{p}<0.1$.

3. In denotes logarithm of the variable. 
Table 10 Impact of Mortgage Payment Ratio on Household Consumption Ratio (Robustness Check Using PSM II)

\begin{tabular}{|c|c|c|c|c|c|c|c|c|c|}
\hline & $\begin{array}{l}(1) \\
\text { totalratio }\end{array}$ & $\begin{array}{l}(2) \\
\text { foodratio }\end{array}$ & $\begin{array}{l}\text { (3) } \\
\text { clothratio }\end{array}$ & $\begin{array}{l}(4) \\
\text { residentratio }\end{array}$ & $\begin{array}{l}\text { (5) } \\
\text { durableratio }\end{array}$ & $\begin{array}{l}(6) \\
\text { medicalratio }\end{array}$ & $\begin{array}{l}(7) \\
\text { transratio }\end{array}$ & $\begin{array}{l}\text { (8) } \\
\text { educateratio }\end{array}$ & $\begin{array}{l}(9) \\
\text { otherratio }\end{array}$ \\
\hline \multirow[t]{2}{*}{ Dmortgage } & $0.0261 * * *$ & $-0.0246 * * *$ & $0.00278 * *$ & $0.00778^{*}$ & $0.0166 * * *$ & $0.00360 *$ & $0.0132 * * *$ & $0.00640 * * *$ & 0.000329 \\
\hline & $(0.00875)$ & $(0.00233)$ & $(0.00112)$ & $(0.00420)$ & $(0.00189)$ & $(0.00201)$ & $(0.00441)$ & $(0.00228)$ & $(0.000768)$ \\
\hline \multirow[t]{2}{*}{ Dmortgage $\times$ mpayratio } & $-0.249 * * *$ & $-0.0718 * * *$ & $-0.0323 * * *$ & 0.00238 & $-0.0168 * *$ & $-0.0340 * * *$ & $-0.0458 * * *$ & $-0.0350 * * *$ & $-0.0154 * * *$ \\
\hline & $(0.0344)$ & $(0.00916)$ & $(0.00442)$ & $(0.0165)$ & $(0.00743)$ & $(0.00793)$ & $(0.0174)$ & $(0.00899)$ & $(0.00302)$ \\
\hline \multirow[t]{2}{*}{ lnpincome } & $-0.144 * * *$ & $-0.114 * * *$ & $-0.00986^{* * *}$ & $-0.0152 * * *$ & 0.00130 & $-0.0114 * * *$ & 0.00433 & -0.00128 & $0.00214 * * *$ \\
\hline & $(0.00621)$ & $(0.00165)$ & $(0.000797)$ & $(0.00298)$ & $(0.00134)$ & $(0.00143)$ & $(0.00313)$ & $(0.00162)$ & $(0.000545)$ \\
\hline \multirow[t]{2}{*}{$l t i$} & $0.123 * * *$ & $-0.0146 * * *$ & $-0.00424 * *$ & $0.0831 * * *$ & $0.0239 * * *$ & $0.00998 * * *$ & 0.00645 & $0.0189 * * *$ & -0.000612 \\
\hline & $(0.0155)$ & $(0.00413)$ & $(0.00199)$ & $(0.00745)$ & $(0.00335)$ & $(0.00357)$ & $(0.00782)$ & $(0.00405)$ & $(0.00136)$ \\
\hline \multirow[t]{2}{*}{ child } & $0.0294 * * *$ & $-0.0239 * * *$ & 0.000747 & -0.00287 & 0.00162 & 0.000262 & 0.00689 & $0.0459 * * *$ & 0.000765 \\
\hline & $(0.00843)$ & $(0.00224)$ & $(0.00108)$ & $(0.00405)$ & $(0.00182)$ & $(0.00194)$ & $(0.00425)$ & $(0.00220)$ & $(0.000740)$ \\
\hline \multirow[t]{2}{*}{ old } & $-0.0262 * * *$ & -0.00372 & $-0.0109 * * *$ & 0.00160 & 0.00120 & $0.00991 * * *$ & -0.00294 & $-0.0229 * * *$ & $0.00155^{*}$ \\
\hline & $(0.00916)$ & $(0.00244)$ & $(0.00118)$ & $(0.00440)$ & $(0.00198)$ & $(0.00211)$ & $(0.00462)$ & $(0.00239)$ & $(0.000805)$ \\
\hline \multirow[t]{2}{*}{ married } & -0.0592 & -0.0241 & -0.00331 & -0.00296 & -0.0197 & -0.00141 & 0.0162 & 0.00344 & $-0.0273 * * *$ \\
\hline & $(0.0693)$ & $(0.0184)$ & $(0.00890)$ & $(0.0333)$ & $(0.0149)$ & $(0.0159)$ & $(0.0349)$ & $(0.0181)$ & $(0.00608)$ \\
\hline \multirow[t]{2}{*}{ age } & $0.00876 * * *$ & $0.00288 * * *$ & $0.000784 * *$ & $-0.00291 * *$ & 0.000116 & $-0.00266 * * *$ & $0.00314 * *$ & $0.00674 * * *$ & $0.000670 * * *$ \\
\hline & $(0.00243)$ & $(0.000647)$ & $(0.000313)$ & $(0.00117)$ & $(0.000525)$ & $(0.000560)$ & $(0.00123)$ & $(0.000635)$ & $(0.000214)$ \\
\hline \multirow[t]{2}{*}{ agesquare } & $-0.0000913^{* * *}$ & $-0.0000258 * * *$ & $-0.0000187 * * *$ & $0.0000367 * * *$ & -0.000000779 & $0.0000332 * * *$ & $-0.0000398 * * *$ & $-0.0000667 * * *$ & $-0.00000937 * * *$ \\
\hline & $(0.0000264)$ & $(0.00000703)$ & $(0.00000340)$ & $(0.0000127)$ & $(0.00000570)$ & $(0.00000609)$ & $(0.0000133)$ & $(0.00000690)$ & $(0.00000232)$ \\
\hline \multirow[t]{2}{*}{ hukou } & 0.00484 & $0.00853^{*}$ & $0.00735 * * *$ & $-0.0358 * * *$ & $0.00902 * *$ & 0.00192 & 0.00974 & 0.00225 & 0.00187 \\
\hline & $(0.0180)$ & $(0.00478)$ & $(0.00231)$ & $(0.00863)$ & $(0.00388)$ & $(0.00414)$ & $(0.00906)$ & $(0.00469)$ & $(0.00158)$ \\
\hline \multirow[t]{2}{*}{ aveincgrowth } & $0.312 *$ & $0.0918 *$ & -0.0246 & 0.0527 & $0.144 * * *$ & 0.00937 & 0.00147 & 0.0220 & 0.0148 \\
\hline & $(0.183)$ & $(0.0487)$ & $(0.0236)$ & $(0.0881)$ & $(0.0395)$ & $(0.0422)$ & $(0.0924)$ & $(0.0478)$ & $(0.0161)$ \\
\hline \multirow[t]{2}{*}{ Inhprice } & -0.0426 & $-0.0254 * *$ & $0.0106 * *$ & $-0.0621 * * *$ & $-0.0202 * *$ & 0.00283 & $0.0598 * * *$ & -0.00795 & -0.000178 \\
\hline & $(0.0384)$ & $(0.0102)$ & $(0.00494)$ & $(0.0185)$ & $(0.00829)$ & $(0.00884)$ & $(0.0194)$ & $(0.0100)$ & $(0.00337)$ \\
\hline \multirow[t]{2}{*}{ pubsavrate } & -0.00931 & 0.00644 & $-0.00686^{* *}$ & $-0.0313 * * *$ & $-0.0132 * * *$ & 0.00772 & $0.0268 * *$ & 0.000912 & 0.000129 \\
\hline & $(0.0234)$ & $(0.00623)$ & $(0.00301)$ & $(0.0112)$ & $(0.00505)$ & $(0.00539)$ & $(0.0118)$ & $(0.00611)$ & $(0.00206)$ \\
\hline
\end{tabular}




\begin{tabular}{|c|c|c|c|c|c|c|c|c|c|}
\hline education and occupation & $\mathrm{Y}$ & $\mathrm{Y}$ & $\mathrm{Y}$ & $\mathrm{Y}$ & $\mathrm{Y}$ & $\mathrm{Y}$ & $\mathrm{Y}$ & $\mathrm{Y}$ & $\mathrm{Y}$ \\
\hline year fixed effect & $\mathrm{Y}$ & $\mathrm{Y}$ & $\mathrm{Y}$ & $\mathrm{Y}$ & $\mathrm{Y}$ & Y & $\mathrm{Y}$ & $\mathrm{Y}$ & $\mathrm{Y}$ \\
\hline region fixed effect & $\mathrm{Y}$ & $\mathrm{Y}$ & $\mathrm{Y}$ & $\mathrm{Y}$ & $\mathrm{Y}$ & $\mathrm{Y}$ & $\mathrm{Y}$ & $\mathrm{Y}$ & $\mathrm{Y}$ \\
\hline \multirow[t]{2}{*}{ _cons } & $2.307 * * *$ & $1.541 * * *$ & 0.0646 & $0.838 * * *$ & $0.207 * * *$ & $0.200 * *$ & $-0.566 * * *$ & -0.00213 & 0.0241 \\
\hline & $(0.348)$ & $(0.0925)$ & $(0.0447)$ & $(0.167)$ & $(0.0750)$ & $(0.0801)$ & $(0.175)$ & $(0.0908)$ & $(0.0305)$ \\
\hline $\mathrm{N}$ & 13770 & 13770 & 13770 & 13770 & 13770 & 13770 & 13770 & 13770 & 13770 \\
\hline R-sq & 0.072 & 0.363 & 0.164 & 0.027 & 0.029 & 0.059 & 0.022 & 0.108 & 0.034 \\
\hline
\end{tabular}

Note: 1. Adopting PSM, we first estimate the probability of having a mortgage payment for each household. We then match each household with a mortgage to a renter, using their probabilities of having a mortgage. Then, we include the interaction term of estimated probability of having a mortgage and mortgage payment ratio and run the regression based on empirical model (2). Columns (1) to and (9) report results after the PSM process. Dependent variables are the household total consumption ratio and consumption ratios of 8 different subcategories of consumption.

2. Robust standard errors are reported in parentheses: $* * *$ denotes $\mathrm{p}<0.01$, $* *$ denotes $\mathrm{p}<0.05$, and $*$ denotes $\mathrm{p}<0.1$.

3. In denotes logarithm of the variable. 
Table 11 Risk Aversion and the Impact of Having a Mortgage on Household Consumption Ratio (Robustness Check)

\begin{tabular}{|c|c|c|c|c|c|c|c|}
\hline \multirow[b]{2}{*}{ regression } & \multirow[b]{2}{*}{ dependent variable } & \multicolumn{3}{|c|}{ High Risk Aversion } & \multicolumn{3}{|c|}{ Low Risk Aversion } \\
\hline & & $\begin{array}{l}\text { coefficient of } \\
\text { Dmortgage }\end{array}$ & standard errors & R-sq & $\begin{array}{l}\text { coefficient of } \\
\text { Dmortgage }\end{array}$ & standard errors & R-sq \\
\hline (2) & foodratio & $0.346^{* * *}$ & $(0.0367)$ & 0.254 & $0.205^{* * *}$ & $(0.0164)$ & 0.325 \\
\hline (3) & clothratio & $-0.0462 * * *$ & $(0.0138)$ & 0.170 & $-0.0708 * * *$ & $(0.00802)$ & 0.207 \\
\hline (4) & residentratio & $0.0652 * *$ & $(0.0295)$ & 0.047 & $0.0865 * * *$ & $(0.0207)$ & 0.014 \\
\hline (5) & durableratio & 0.0211 & $(0.0156)$ & 0.016 & -0.00835 & $(0.0105)$ & 0.017 \\
\hline (6) & medicalratio & 0.0136 & $(0.0326)$ & 0.043 & -0.00196 & $(0.0144)$ & 0.076 \\
\hline (7) & transratio & 0.0327 & $(0.0356)$ & 0.016 & $0.218 * * *$ & $(0.0291)$ & 0.029 \\
\hline (8) & educateratio & $0.0727 * *$ & $(0.0341)$ & 0.102 & $-0.113 * * *$ & $(0.0174)$ & 0.104 \\
\hline (9) & otherratio & 0.00352 & $(0.00835)$ & 0.033 & 0.00199 & $(0.00577)$ & 0.032 \\
\hline
\end{tabular}

Note: 1. We first use a tobit model to predict the ratio of risky assets to liquid assets, using the demographic and financial information about households from the UHS database. We use this ratio as a proxy for risk attitude. We then divide the sample into high risk-aversion and low risk-aversion groups using the median value of risk aversion as the threshold level. For each group, we separately run the consumption regressions and compare the coefficients for estimated probability of having a mortgage (Dmortgage).

2. Rows (1) to (9) report results based on empirical model (1). Dependent variables are the household total consumption ratio and consumption ratios of 8 different subcategories of consumption. The independent variables are the same as in Table 3.

3. Robust standard errors are reported in parentheses: $* * *$ denotes $\mathrm{p}<0.01, * *$ denotes $\mathrm{p}<0.05$, and $*$ denotes $\mathrm{p}<0.1$. 


\section{References}

Ahuvia, A., \& Wong, N. (1998). The Effect of Cultural Orientation in Luxury Consumption. Advances in Consumer Research, 25, 29-32.

Chamon, M. D., \& Prasad, E. S. (2010). Why Are Saving Rates of Urban Households in China Rising? American Economic Journal: Macroeconomics, 2(1), 93-130.

Calza, Alessandro, Tommaso Monacelli, and Livio Stracca. (2013). Housing Finance and Monetary Policy. Journal of the European Economic Association, 11, 101-122.

Campbell, J. Y., \& Cocco, J. F. (2007). How Do House Prices Affect Consumption? Evidence from Micro Data. Journal of Monetary Economics, 54(3), 591-621.

Choi, H., Lugauer, S., \& Mark, N. C. (2014). Precautionary Saving of Chinese and U.S. Households. NBER Working Paper No: 20527.

Cox, R., Brounen, D., \& Neuteboom, P. (2015). Financial Literacy, Risk Aversion and Choice of Mortgage Type by Households. The Journal of Real Estate Finance and Economics, 50(1), 74-112.

Cronqvist, H., \& Siegel, S. (2015). The Origins of Savings Behavior. Journal of Political Economy, 123(1), $123-169$.

Engelhardt, G. V. (1996). House Prices and Home Owner Saving Behavior. Regional Science and Urban Economics, 26(3), 313-336.

Engelhardt, G. V. (1996). Consumption, Down Payments and Liquidity Constraints. Journal of Money, Credit, and Banking, 28, 255-271.

Feldstein, M., \& Horioka, C. (1980). Domestic Saving and International Capital Flows. Economic Journal, 90, 314-29.

Hogarth, J. M., \& Hilgert, M. A. (2002). Financial Knowledge, Experience and Learning Preferences: Preliminary Results from a New Survey on Financial Literacy. Consumer Interest Annual, 48(1), $1-7$.

Horioka, C. Y., and Wan, J. (2007). The Determinants of Household Saving in China: A Dynamic Panel Analysis of Provincial Data. Journal of Money, Credit, and Banking, 39(2), 2078- 2096.

Huston, S. J. (2010). Measuring Financial Literacy. Journal of Consumer Affairs, 44(2), 296-316.

Jappelli, T., \& Pagano, M. (1994). Saving, Growth, and Liquidity Constraints. The Quarterly Journal of Economics, 109(1), 83-109.

Juster, E. T., Lupton, J. P., Smith, J. P., \& Stafford, F. (2003). The Decline in Household Saving and the Wealth Effect. The Review of Economics and Statistics, 87(4), 20-27.

Kindel, T. I. (1985). Chinese Consumer Behavior: Historical Perspective Plus an Update on Communication Hypotheses. SV-Historical Perspective in Consumer Research: National and International Perspectives.

Liao, W.-C., Zhao, D., \& Sing, T. F. (2014). Risk Attitude and Housing Wealth Effect. The Journal of Real Estate Finance and Economics, 48(3), 467-491.

Loayza, N., Schmidt-Hebbel, K., \& Serven, L. (2000). What Drives Private Saving Across the World?. The Review of Economics and Statistics, 82(2), 165-181.

Ludwig, A., \& Slok, T. (2004). The Relationship between Stock Prices, House Prices and Consumption in OECD Countries. The B.E. Journal of Macroeconomics, 4(1), 1-28. 
Lusardi, A., \& Mitchell, O. S. (2007). Baby Boomer Retirement Security: The Roles of Planning, Financial Literacy, and Housing Wealth. Journal of monetary Economics, 54(1), 205-224.

Manchester, J. M., \& Poterba, J. (1989). Second Mortgages and Household Saving. Regional Science and Urban Economics, 19, 325-46.

Morrison, G. C. (1998). Understanding the Disparity between Wtp and Wta: Endowment Effect, Substitutability, or Imprecise Preferences? Economics Letters, 59(2), 189-194.

Plott, C. R., \& Zeiler, K. (2005). The Willingness to Pay-Willingness to Accept Gap, The. The American Economic Review, 95(3), 530-545.

Read, D., Loewenstein, G., Rabin, M., Keren, G., \& Laibson, D. (1999). Choice Bracketing Elicitation of Preferences (pp. 171-202): Springer.

Shefrin, H. M., \& Thaler, R. H. (2004). Mental Accounting, Saving, and Self-Control. Advances in behavioral economics, 395-428.

Skinner, J. (1988). Risky Income, Life Cycle Consumption and Precautionary Savings. Journal of Monetary Economics, 22(2), 237-255.

Tunc, C., \& Yavas, A. (2016). Not All Credit Is Created Equal: Mortgage Vs Non-Mortgage Debt and Private Saving Rate in Turkey. Central Bank Review, 16(1), 25-32.

Tunc, C., \& Yavas, A. (2017). Collateral Damage: The Impact of Mortgage Debt on U.S. Savings. Housing Policy Debate, forthcoming.

Turvey, C. G., \& Kong, R. (2010). Informal Lending Amongst Friends and Relatives: Can Microcredit Compete in Rural China? China Economic Review, 21(4), 544-556.

Van Rooij, M., Lusardi, A., \& Alessie, R. (2011). Financial Literacy and Stock Market Participation. Journal of Financial Economics, 101(2), 449-472. 